\title{
Transforming growth factor- $\beta$ superfamily, implications in development and differentiation of stem cells
}

\author{
Juan F. Santibanez* and Jelena Kocic \\ Laboratory for Experimental Hematology and Stem Cells, \\ Institute for Medical Research, University of Belgrade, \\ Dr Subotića 4, 11129 Belgrade, Serbia \\ * Corresponding author \\ e-mail: jfsantibanez@imi.bg.ac.rs
}

\begin{abstract}
Transforming growth factor- $\beta$ (TGF- $\beta$ ) family members, including TGF- $\beta$ s and bone morphogenetic proteins (BMPs), play important roles in directing the fate of stem cells. In embryonic stem cells, the TGF- $\beta$ superfamily participates in almost all stages of cell development, such as cell maintenance, lineage selection, and progression of differentiation. In adult mesenchymal stem cells (MSCs), TGF- $\beta$ s can provide competence for early stages of chondroblastic and osteoblastic differentiation, but they inhibit myogenesis, adipogenesis, and late-stage osteoblast differentiation. BMPs also inhibit adipogenesis and myogenesis, but they strongly promote osteoblast differentiation. The TGF- $\beta$ superfamily members signal via specific serine/threonine kinase receptors and their nuclear effectors termed Smad proteins as well as through non-Smad pathways, which explain their pleiotropic effects in self-renewal and differentiation of stem cells. This review summarizes the current knowledge on the pleiotropic effects of the TGF- $\beta$ superfamily of growth factors on the fate of stem cells and also discusses the mechanisms by which the TGF- $\beta$ superfamily members control embryonic and MSCs differentiation.
\end{abstract}

Keywords: BMP; differentiation; signaling; stem cells; TGF- $\beta$.

\section{Introduction}

The transforming growth factor $\beta$ (TGF- $\beta$ ) superfamily involves a large number of factors related both structurally and functionally, which act as multifunctional regulators of diverse biological processes. The members of the TGF- $\beta$ superfamily are implicated in morphogenesis, embryonic development, immune regulation, wound healing, inflammation, and cancer $(1,2)$. In the last decade, the TGF- $\beta$ superfamily has been described as a main component of the regulatory network that modulates lineage commitment and differentiation of stem cells. The pleiotropic effects of the TGF- $\beta$ superfamily members are part of a finely orchestrated signaling activity, which correlates with tempo-spatial regulation of ligands, receptors, and intracellular signal transducers, each tightly regulated during embryonic and adult stem cell differentiation (3).

In the present review, first, the molecular components involved in the TGF- $\beta$ family signaling, such as ligands, receptors, as well as Smads and non-Smad signaling pathways, which collectively clarify the plethoric diversity of functions of the TGF- $\beta$ superfamily, will be described. Second, the diverse roles of the TGF- $\beta$ family members in the regulation of embryonic stem cells (ESCs) and adult mesenchymal stem cells (MSCs) behavior, mainly focusing on the process of cell differentiation will be described.

\section{TGF- $\beta$ superfamily}

The TGF- $\beta$ superfamily of secreted growth factors comprises more than 40 ligands that, despite exhibiting pronounced structural similarities (such as their dimeric structure and presence of a cysteine knot motif), function as regulators of a variety of divergent processes both during embryogenesis and later on in adult homeostasis $(2,4,5)$. These proteins can be classified into subfamilies, such as TGF- $\beta$ s, bone morphogenetic proteins (BMPs), growth and differentiation factors (GDFs), Müllerian inhibitory factor (MIF), and activins/ inhibins (Table 1) (2).

Transforming growth factors were discovered in studies of platelet-derived growth factor (PDGF) and epidermal growth factors (EGF/TGF $\alpha$ ) and were named according to their capacity to 'transform' fibroblast rat cells in vitro (6). Six distinct isoforms of TGF- $\beta$ with a degree of homology of $64-82 \%$ have been discovered, although only the TGF$\beta 1,-\beta 2$, and $-\beta 3$ isoforms are expressed in mammals (7). The expression of the three isoforms is differently regulated at the transcriptional level due to different promoter sequences. The TGF- $\beta 1$ promoter lacks the classic TATAA box but possesses multiple regulatory sites that can be activated by a number of immediate early genes and oncogenes and is inhibited by tumor suppressors $(8,9)$. The TGF- $\beta 2$ and $-\beta 3$ promoters each contain TATAA boxes and a common proximal CREATF site, suggesting their role in hormonal and developmental control (10-12).

The three TGF- $\beta$ s: $\beta 1, \beta 2$, and $\beta 3$ isoforms are synthesized as pro-peptide precursors with a signal domain followed by the prodomain [also named latency-associated peptide (LAP)] and the mature domain (13). The signal domain is removed in the endoplasmic reticulum, and then, a new cleavage by the convertase family of endoproteases occurs between the LAP and the mature peptide (14). After cleavage, the LAP remains associated with the mature domain forming a small latent complex (SLC) until dissociation to release bioactive 
Table 1 Members of the mammalian TGF- $\beta$ superfamily.

\begin{tabular}{lll}
\hline TGF- $\beta$ s & BMP and GDF & Activins, inhibins \\
\hline TGF- $\beta 1$, & BMP2, BMP3b/GDF10, BMP4, BMP5, BMP6, BMP7, BMP8a, & Activin A, Activin B, Activin \\
TGF- $\beta 2$, & BMP8b, BMP9/GDF2, BMP10, BMP11/GDF11, BMP12/GDF7, & AB, Activin C, Activin E \\
TGF- $\beta 3$ & BMP13/GDF6, BMP14/GDF5, BMP15/GDF9b, BMP16/Nodal, & Inhibin A, Inhibin B, Inhibin C \\
& GDF1, GDF3, GDF8/myostatin, GDF9, GDF15 & \\
\hline
\end{tabular}

The four majors groups of TGF- $\beta$ superfamily are represented. Adapted from (2).

TGF- $\beta$. After secretion, the SLC is covalently associated with the latent TGF- $\beta 1$-binding proteins (LTBPs) through the LAP forming the large latent complex (LLC), which is also bound to the extracellular matrix proteins, such as fibronectin and fibrillin $(13,15)$. Different mechanisms, which depend on the cell type and context, have been proposed for the release of the TGF- $\beta$ from LLC, including trombospondin interaction with LAP (16), proteolitic cleavage of LAP by matrix metalloproteinases and urokinase-type plasminogen activator/plasmin system $(17,18)$. Although all components of the TGF- $\beta$ family are synthesized as precursor proteins containing a LAP, the capacity of the LAP to maintain the TGF- $\beta$ ligand in latent form is not conserved among all proteins (13).

BMPs were originally identified as factor(s) that induce the formation of bone and cartilage when implanted at ectopic sites (19). BMP-like molecules have been found in vertebrates as well as in invertebrates. BMPs are now well known to exhibit a wide range of biological effects on various cell types (20, 21). Nine different types of BMPs have been described and can be further classified into several subgroups, including the BMP-2/4 group, the BMP-5/6/7/8 group (OP-1 [osteogenic protein-1] group), and the BMP-9/10 group (21).

Dissimilar to the TGF- $\beta$ s, the BMPs are mainly secreted in active form, and their activities are regulated by BMP antagonists, which can bind the BMPs directly to prevent them from interacting with their respective membrane receptors. Four subfamilies of the BMP antagonists have been described based on the size of their cysteine knot (a common arrangement of six half cystine residues to three intrachain disulfide bonds) (22): 1) the Dan family, 2) the chordin family, 3) twisted gastrulation, and 4) the Noggin family $(23,24)$. These BMP antagonists have differential affinities for different BMPs. Interestingly, positive regulators of the BMP have also been described; for example, kielin/chordinlike protein $(\mathrm{KCP})$, a secreted protein with $18 \mathrm{CR}$ domains increases the binding of BMP7 to its receptor and enhances downstream signaling pathways (25). Conversely, the KCP can inhibit both activin-A and the TGF- $\beta 1$-induced activation of Smad2/3 pathway. In addition, crossveinless $2(\mathrm{Cv} 2)$ is a pro-BMP factor during embryogenesis (26).

GDFs were discovered searching for additional members of the TGF- $\beta$ superfamily and are classified as a group in the BMP subfamily, together forming a single family of cystineknot cytokines, which in itself constitute the largest subfamily of the TGF- $\beta$ superfamily (27). At least 11 components of GDFs have been described: GDF1-3, GDF5-11, and GDF15 (28).
The MIF, also known as anti-Müllerian hormone (AMH), has been mainly studied for its regulatory role in male sex differentiation (29). The MIF is implicated in the regression of Müllerian ducts in male fetuses during development as well as in the function of the gonads of both sexes (30).

Activins (ACVs) are structurally related proteins involved in the control of cell proliferation, differentiation, apoptosis, metabolism, homeostasis, differentiation, immune response, and endocrine function (31). Activins possess a cysteine knot scaffold and are secreted as homodimers or heterodimers of inhibin $b$ subunits. Although four b-subunit genes ( $\beta \mathrm{A}$, $\beta B, \beta C$, and $\beta E$ ) have been described in humans, only dimers composed of $\beta \mathrm{A} / \beta \mathrm{A}$ (activin $\mathrm{A}$ ), $\beta \mathrm{B} / \beta \mathrm{B}$ (activin $\mathrm{B}$ ), and $\beta \mathrm{A} / \beta \mathrm{B}$ (activin $\mathrm{AB}$ ) subunits have been shown to be biologically active (32).

Inhibins are peptide hormones originally characterized as proteins produced by the gonads that act in an endocrine manner to negatively regulate follicle-stimulating hormone (FSH) synthesis and secretion from the anterior pituitary. As such, inhibins are essential for normal reproductive and endocrine function (33). Additionally, inhibins are closely related to activins. Inhibins are disulfide-linked heterodimers comprising an $\alpha$-subunit and either a $\beta$ A or $\beta B$ subunit to form inhibin A and inhibin B, respectively (Table 1).

\section{The TGF- $\beta$ receptors}

Both the TGF- $\beta$ s and BMPs bind to their cell surface receptors to form heteromeric complexes. Dimers of types I and II serine/threonine kinase receptors interact with the dimeric ligand (Table 2 and Figure 1). Seven type I [activin-like kinase (ALK1-7)] and five type II receptors [TGF- $\beta$ receptor (TGFBR2), bone morphogenetic protein receptor 2 (BMPR2), activin receptor 2 (ACVR2), ACVR2B, and AMHR2] have been described where the differential affinities for the individual ligand contribute to signaling specificity (Table 2) (2, 34). Crystal structures of the respective ternary complexes reveal notable differences regarding the topology of these complexes between the TGF- $\beta$ s and the BMPs (35). The TGF- $\beta$ s and BMPs can also bind to preformed complexes of type I and II receptors $(4,36)$ In addition, the TGF- $\beta$ ligands can interact with the co-receptors, type III receptor, endoglin and betaglican, which both drive ligand binding and modulate the receptor kinase transduction $(1,37)$.

The ligand first binds to the type I receptor, which is then phosphorylated at the 'GS' domain by the constitutively 
Table 2 TGF- $\beta$ superfamily, overview of their binding specificity and ligand-receptor-Smad relationships (162).

\begin{tabular}{|c|c|c|c|}
\hline Ligands & Type I receptor & Type II receptor & R-Smads \\
\hline TGF- $\beta$ & \multirow[t]{2}{*}{ ALK1/ACVRLI } & TGFBR2/TBRII & \multirow[t]{6}{*}{ Smad1,5,8 } \\
\hline BMP9, 10 & & BMPR2/BMPRII, ACVR2/ActRIIA & \\
\hline \multirow[t]{3}{*}{ BMPS/GDFS } & ALK2/ACVRI & BMPR2, ACVR2 & \\
\hline & ALK6/BMPRIB & BMPR2, ACVR2, ACVR2B/ActRIIB & \\
\hline & \multirow[t]{2}{*}{ ALK3/BMPRIA } & BMPR2 & \\
\hline MIF/AMH & & AMHR2/AMHRII & \\
\hline Nodal/GDF16 & \multirow[t]{2}{*}{ ALK4/ACVRIB } & \multirow[t]{3}{*}{ ACVR2, ACVR2A } & \multirow[t]{5}{*}{ Smad2,3 } \\
\hline Activins & & & \\
\hline Myostatin/GDF8, GDF11 & \multirow{2}{*}{ ALK5/TGFBRI } & & \\
\hline TGF- $\beta$ & & TGFBR2 & \\
\hline Nodal/GDF16 & ALK7/ACVRIC & ACVR2, ACVR2B & \\
\hline
\end{tabular}

active type II receptor producing a ligand-receptor complex in activated state (38). Phosphorylation of the type I receptor disrupts the interaction between the kinase domain and a TGF- $\beta$ signaling inhibitor, FKBP12 (39). In addition, the phosphorylation of the GS domain changes to more acidic surface ambient, allowing the recruitment of the downstream

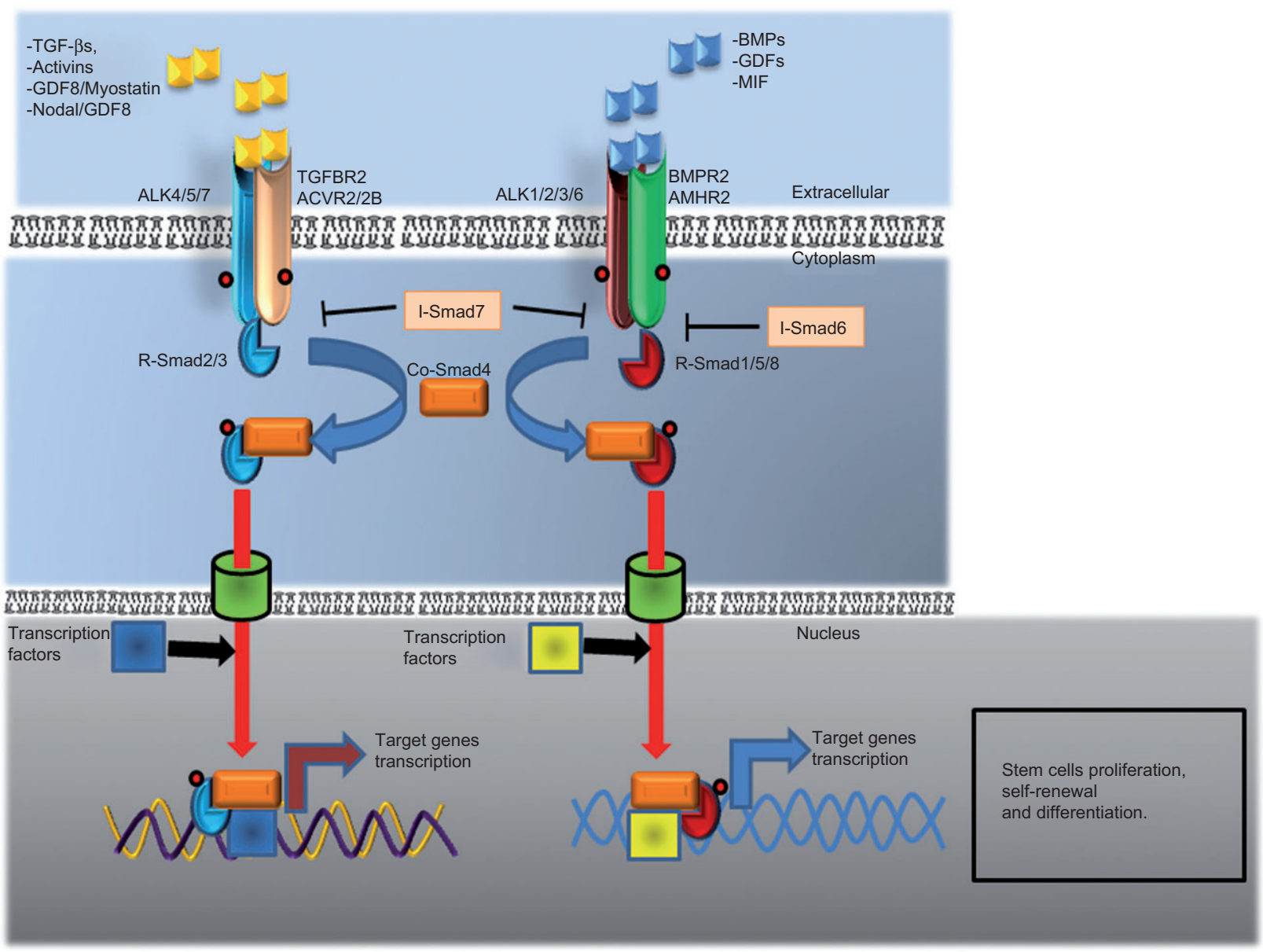

Figure 1 The TGF- $\beta$ superfamily signal transduction through Smads pathways.

Binding of different TGF- $\beta$ superfamily ligands to receptors triggers the heterodimeric formation of active receptor complexes. Type I receptor is activated by type II receptor and phosphorylated R-Smads (red circles), then activated R-Smads are released from the inner face of the cytoplasmic membrane to associate with Co-Smad4, and are translocated and accumulated inside the nucleus. Smad complexes interact with other transcription factors to bind specific DNA domains in the promoters of target genes to modulate cell responses. 
effectors Smads, which are then phosphorylated by the type I receptor through the interaction with the Smads' basic domain (40).

The TGF- $\beta$ super family of receptors is subjected to posttranslational modifications, such as phosphorylation/dephosphorylation, sumoylation, and ubiquitylation, which regulate the TGF- $\beta$ receptor stability and availability. These modifications are part of the fine tuning involved in the TGF- $\beta$ superfamily signal transduction modulation, resulting as key determinants in the TGF- $\beta$ cellular responses (41).

The phosphorylation of the receptors is important for the activation of the signal transduction by the TGF- $\beta$ superfamily, while the dephosphorylation of the receptors is an important event in the regulation of their activity. In mammalian cells, Smad7 (an inhibitory Smad, described below) has been shown to recruit a phosphatase complex of GADD34 and protein phosphatase PP1c to the activated TGF- $\beta$ type I receptor (ALK5), in order to dephosphorylate and inactivate the receptor (42). Dullard, a protein involved in neural induction, negatively regulates BMP signaling by promoting proteosomal degradation of BMP type II receptor and repressing BMP type I receptor phosphorylation, where the phosphatase domain in Dullard is indispensable for its ability to degrade the BMP receptor complex (43).

Sumoylation, the covalent attachment of a SUMO polypeptide by sequential actions of E1, E2, and E3 SUMO ligases, is an important mechanism of the TGF- $\beta$ receptor regulation (44). ALK5 can be sumoylated by a yet unknown sumoligase in mammalian cells, which requires the kinase activities of both type I and II receptors. ALK5 sumoylation enhances TGF- $\beta$-Smads signaling (45). These studies have mainly been done using the TGF- $\beta$ receptors, and further studies are necessary to elucidate the BMP receptor modifications.

Another point of modulation is the regulation of the level of the TGF- $\beta$ receptors. The ligand/receptor complexes can be internalized via lipid rafts/caveolae to be degraded inside a proteosome (46). The TGF- $\beta$ receptor degradation is dependent on their association with inhibitory Smads (I-Smads; Smad6 and Smad7) and homologous to E6-AP carboxyl terminus (HECT)-type E3 ligases Smurf1 and Smurf2 (Smurf ubiquitin ligases). Thus, Smurfs/I-Smads regulate the intracellular pool of the TGF- $\beta$ receptors and inhibit the TGF- $\beta$ superfamily signaling. Smad6 and Smad7 recruit Smurf ubiquitin ligases to induce ubiquitination and degradation of the TGF- $\beta$ receptors $(47,48)$.

\section{TGF- $\beta$ superfamily signal transduction}

\section{Smads-dependent signaling}

The first described member of Smads is Mothers Against Decapentaplegic (MAD), identified from genetic screens in Drosophila melanogaster. Three Caenorhabditis elegans MAD homologs are named sma2, sma-3, and sma-4. The Mammalian homolog Smad is a combination/contraction of Sma and MAD (49).
The activated receptor complexes transduce intracellular signaling by the type I receptor phosphorylation of Smads in their carboxy-terminal domains (50). In unphosphorylated form, the Smads are transcriptionally inactive and sequestered by the cytoplasmic retention proteins such as Smad anchor for receptor activation (SARA) (51).

In humans, eight different types of well-conserved Smads are described (Smad1-8). These Smads are classified into three sub groups: i) receptor associated-Smads (R-Smads); ii) common Smad (Co-Smad); and iii) inhibitory Smads (I-Smads).

The five R-Smads that have been described (Smad1, 2, 3, 5 , and 8 ), are substrates for activated TGF- $\beta$ receptors. Smad2 and Smad 3 are mainly substrates for the TGF- $\beta$ and ACVs, whereas Smad1, 5, and 8 are mainly substrates for BMP, GDF, and MIF receptors $(2,4,21)$ (Table 2 and Figure1).

R-Smad proteins consist of three domains: two highly conserved domains at the $\mathrm{N}$-terminus and at the C-terminus, the Mad homology domain 1 (MH1) and the Mad homology domain 2 (MH2), respectively; 1) MH1 interacts with specific domains in the DNA as well as with other proteins and also has a nuclear localization signal (NLS), and 2) MH2 that mediates the homo- or hetero-oligomerization of the Smads and the transactivation of Smads nuclear complexes. The third domain is the highly variable linker region existing between MH1 and MH2 domains, which is enriched in prolines and is a potential serine/theronine substrate for phosphorylation $(2,52)$.

All activated R-Smads, after the phosphorylation of the TGF- $\beta$ receptors, are released from the cytoplasmic membrane and interact with the Co-Smad (Smad4). Smad4 has an insertion in the MH2 motif and lacks the C-terminal motif for type I receptor phosphorylation (53). The activated Smads complex, a trimer consisting of a single Co-Smad and homo or heterodimer of R-Smads, is then shuttled into the nucleus where it binds to promoters of the target genes with other transcription factors (50). Two of these genes are the third component of Smads, the I-Smads: Smad6 and Smad7. I-Smads expression produces a negative feedback regulation of TGF- $\beta$ signaling (54). These I-Smad proteins contain a characteristic $\mathrm{C}$-terminal $\mathrm{MH} 2$ domain, but they lack the conserved MH1 domain. SMAD6 preferentially inhibits BMP signaling displacing Smad1-Co-Smad interaction and forms an inactive Smad1-Smad6 complex. Smad7 inhibits R-Smad phosphorylation by binding the TGF- $\beta$, activin, and the BMP type I receptors (55).

In the nucleus, Smad protein complexes can bind directly to DNA with weak affinity to Smad-binding elements (SBEs) to regulate the transcription of target genes. Smad3/Smad4 complexes recognize a five-base pair -GTCTG- or -CAGACsequence, whereas Smad1, -5 , and 8 bind to the AGAC/GTCT sequence only weakly and also recognize GC-rich regions (such as GGCGCC) in some target genes $(2,56,57)$.

In Smad2, a 30-amino acid insertion encoded by exon 3 in the MH1 domain disables its binding to DNA. The binding of Smad complexes to DNA, although at a low affinity, has been shown to be crucial for the transcriptional activation of Smad target genes; it is certain that binding to chromatin, to form 
transcriptional complex with high-affinity to DNA, requires interactions with different transcription factors (50).

In addition, and in relation to R-Smad types, the TGF- $\beta$ superfamily ligand can be classified into two main branches: TGF- $\beta$ /activin branch that signals to the nucleus through Smads2/3 and the BMP/GDF branch that signals through Smads 1/5/8 (21).

\section{Non-Smad pathways}

The relative simplicity of the Smads signaling model produces a dilemma in the understanding of the plethoric diversity of functions of the TGF- $\beta$. In fact, is it well known that the TGF- $\beta$ superfamily signaling pathways are not limited to Smad-mediated pathways, but can be determined by a crosstalk of non-Smad intracellular signal pathways, which may, in alternate way, modulate cellular responses. These non-Smad pathways include mitogen-activated protein kinase (MAPK)

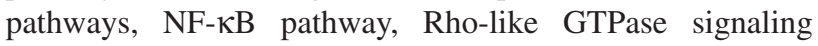

pathways, and phosphatidylinositol-3-kinase (PI3K)/AKT pathways (Figure 2) (58). Briefly, one of the first indications that the TGF- $\beta$ activates a pathway different than Smads came from the observation of Ras activation by TGF- $\beta 1$ in epithelial cells (59), allowing the possibility that the TGF- $\beta$ may also activate ERK MAPK. Recently, Lee et al. (60) demonstrated that the TGF- $\beta$ receptor type I/ALK5 can also be tyrosine phosphorylated after TGF- $\beta$ stimulation, when activated ALK5 recruits and phosphorylates both serine and tyrosine residues in the ShcA adaptor, thus promoting the formation of a ShcA/Grb2/Sos complex. This triggers the activation of Ras-Raf-ERK MAPK cascade, which can regulate cell growth, proliferation, or migration.

The TGF- $\beta$ s, independent of the receptor's kinase activities (61), are also enable to activate the p38 and c-Jun N-terminal kinase (JNK) MAPKs, by the recruitment of the ubiquitin ligase tumor necrosis factor $\alpha$ receptor-associated factor 6 (TRAF6) to the ALK5 cytoplasmic domain, which in turn activates transforming-growth-factor- $\beta$-activated kinase 1

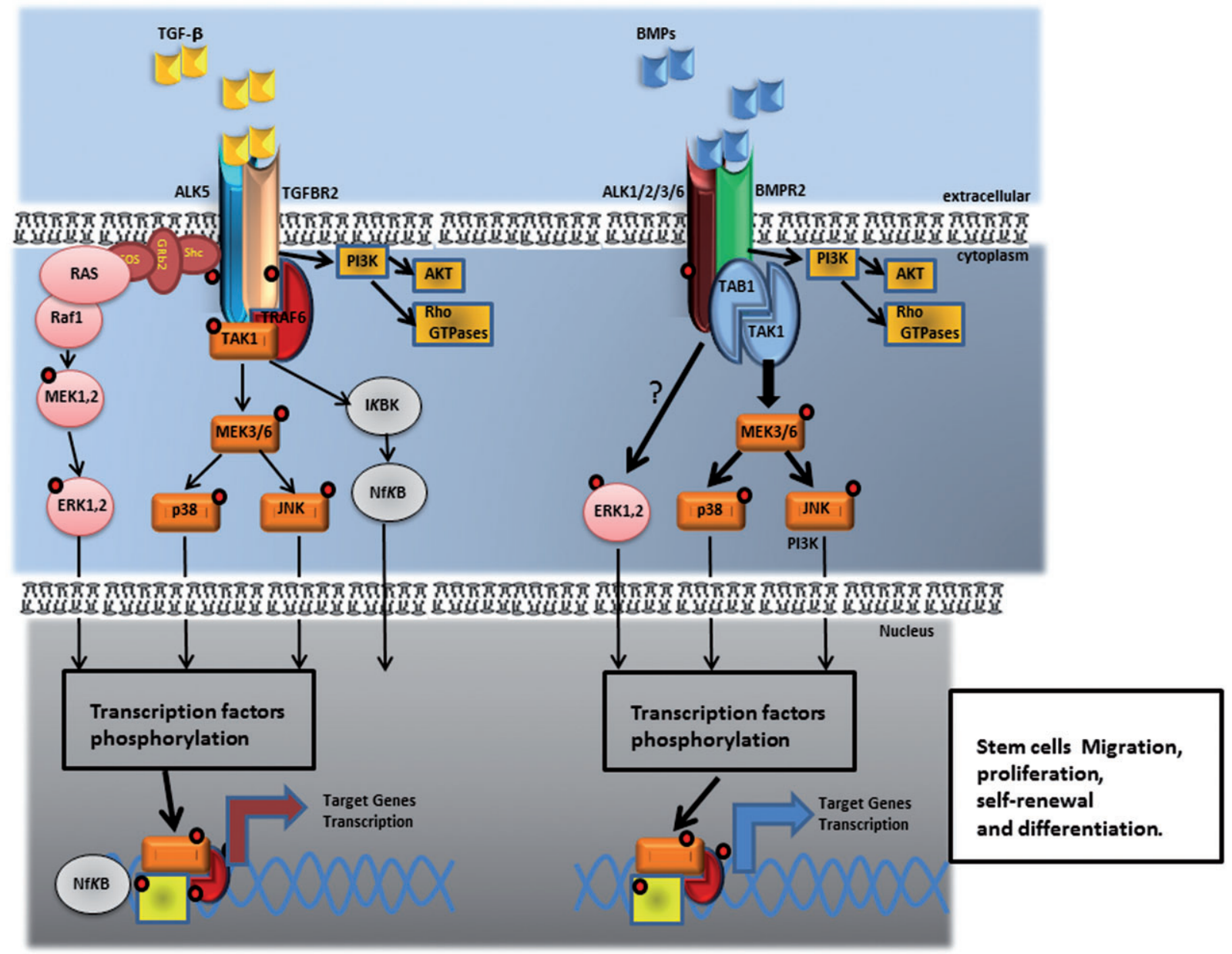

Figure 2 Non-Smad TGF- $\beta$ superfamily signal transduction.

Upon TGF- $\beta$ binding, activated receptors interact with TRAF6, which recruits TAB1 and TAK1 to activate p38, JNK, and NF- $\mathrm{kB}$ pathways. Also, TGF- $\beta$ binding induces ALK5 phosphorylation in serine and/or tyrosine residues, then TGFBRs/Shc/Grb2/SoS complex is formed to, in turn, activate Ras/Raf1/MEK1,2/ERK1,2 signaling. On the other hand, BMPs bound to receptors also trigger the recruitment of XIAP, TAB1, and TAK1 to activate $\mathrm{p} 38$ and JNK signaling; also, in a non-elucidated way, BMPs can activate ERK1,2 signaling. Both TGF- $\beta$ and BMPs can activate PI3K to regulate the activity of AKT and small Rho GTPases. The activation of non-Smad signal pathways, in turn, initiates transcriptional or nontranscriptional activities to regulate cellular responses. 
(TAK1), MEKK4, and MEKK3/6 to produce the activation of JNK and p38, respectively, and further on regulate apoptosis, differentiation, or cell migration $(61,62)$. BMPs also activate MAPK cascades, mediated by XIAP/TAK-binding protein 1 (TAB1)/TAK1, leading to the activation of p38 and JNK (4). Although BMPs also activate ERK signaling (4), the mechanisms have not been elucidated so far.

Like MAPK pathways, the Rho-like GTPases, including RhoA, Rac, and Cdc42 are also key players in TGF- $\beta$ signaling. TBRII phosphorylates the polarity protein PAR6, which regulates the local degradation of RhoA, that in turn produces a tight junction dissemble and a rearrangement of actin cytoskeleton with the consequence of epithelial architecture disintegration to finally induce the epithelial mesenchymal transition (EMT), an important developmental and diseaseassociated process that is regulated by TGF- $\beta$ signaling (63, 64). BMPs are also able to activate Rho-like GTPases, with BMP2 activating Cdc42 in neurons and myoblasts, and BMP7 activate RhoA in fibroblasts $(65,66)$.

As a final example and similar to various growth factors, TGF- $\beta$ has been shown to rapidly activate PI3 kinase, leading to activation of the Akt kinase, in diverse cell systems. This activation appears to be independent of Smad2/3 activation (67), whereas the kinase activities of the TGF- $\beta$ receptors are required for TGF- $\beta$-induced PI3K activation (68). Interestingly, the PI3K/Akt pathway may antagonize Smadmediated effects and protect cells from TGF- $\beta$-induced apoptosis and growth inhibition $(69,70)$.

\section{TGF- $\beta$ superfamily in development and differentiation of stem cells}

The TGF- $\beta$ superfamily has been implicated in the development and maintenance of various organs in which stem cells play important roles. Stem cells are characterized by their ability to self-renew and to generate differentiated cells of a particular tissue and can be classified into embryonic and adult stem cells. The TGF- $\beta$ s have emerged as key players in self-renewal and maintenance of ESCs and adult stem cells in their undifferentiated state, the selection of cell fate, and the progression of differentiation along a lineage (71).

\section{TGF- $\beta$ family signaling during in vitro differentiation of embryonic stem cells}

ESCs are derived from inner mass of blastocysts, multicellular structures originating from four (human) to five (mouse) cleavages of fertilized oocytes. The ESCs retain their capacity of self-renewal (symmetric division without differentiation to produce identical daughter cells) and the potential to be committed and to differentiate into all three germ layers, namely, the ectoderm, the mesoderm, and the endoderm and then into diverse cell types of the organism (72-75).

During in vitro differentiation, both murine and human ESCs can recapitulate embryonic development at early stages and can undergo multilineage differentiation to generate cells with well-differentiated phenotypes (76). This makes ESCs a unique model for understanding and studying early embryonic development of mammalian cells in vitro and opens new routes in pathophysiological biology and therapeutic application in regenerative medicine.

\section{TGF- $\beta$ s in germ layer specification}

The TGF- $\beta$ superfamily plays a major role in the biology of development. These proteins are broadly expressed throughout the body and regulate many cellular physiological processes including cell fate, cell proliferation, cell senescence, and tissue repair $(77,78)$. The TGF- $\beta$ ligands are implicated in the self-renewal, maintenance, and regulation of differentiation of ESCs (78). Differentiation of the three germ layers from ESCs is regulated by a combination of TGF- $\beta$ superfamily ligands (79). Ectoderm specification requires the TGF- $\beta$ response to be attenuated (80) and is differentiated from mouse and human ESCs in the absence of TGF- $\beta$ family signals, while primitive streak differentiation is induced by BMP and activin/Nodal $(81,82)$. Mesoderm is differentiated from the primitive streak region in the presence of BMP, and a medium level of activin/Nodal signals, and is enhanced by inhibition of TGF- $\beta$ signaling $(83,84)$. Differentiation into endoderm is induced by a high level of activin/Nodal signals in the absence of serum, whereas BMPs inhibit endoderm differentiation induction $(85,86)$ (Figure 3 ).

Mesodermal derivatives are the hematopoietic, vascular, cardiac, myogenic, adipogenic, and chondrogenic cell lineages developed from the mesoderm in embryos (77). Some examples of the involvement of TGF- $\beta$ s in the differentiation of different mesodermal derivatives will be described next.

Cardiomyogenesis TGF- $\beta$, BMP2, and BMP4 are all able to trigger expression of mesodermal and cardiacspecific genes in mouse ESCs, such as Brachyury and Mef2c, respectively (77). Generation of cardiomyocytes from ESCs has been of interest for the treatment of cardiac diseases and hearth regeneration. ESC differentiation to cardiomyocytes has been done using embryonic body (EB) formation under a low concentration of activin $(10 \mathrm{ng} / \mathrm{ml})$ (81). In human ESCs, the treatment with activin followed by BMP4 was used to induce the differentiation into cardiomyocytes (87). BMP2-induced mesodermal and cardiac specification is translated into a full cardiogenic differentiation program leading to an enrichment of cardiomyocytes within EB. The BMP-dependent cardiogenesis was observed when TGF- $\beta$ or BMP2 was added to ESCs prior to differentiation or in the early step of EB formation (88). Interestingly, a transient inhibition of BMP signaling by Noggin, between mesodermal induction and cardiomyocyte differentiation stages, appears to be a critical step for cardiomyogenesis determination (89). These observations suggested that a temporal and spatial BMP expression and signaling regulation are critical for cardiomyocyte induction.

Endothelial and hematopoietic differentiation During embryonic development, the endothelial and hematopoietic lineages are derived from the yolk sac mesoderm (77). The hematopoietic cells and vascular endothelium cell progenitors 


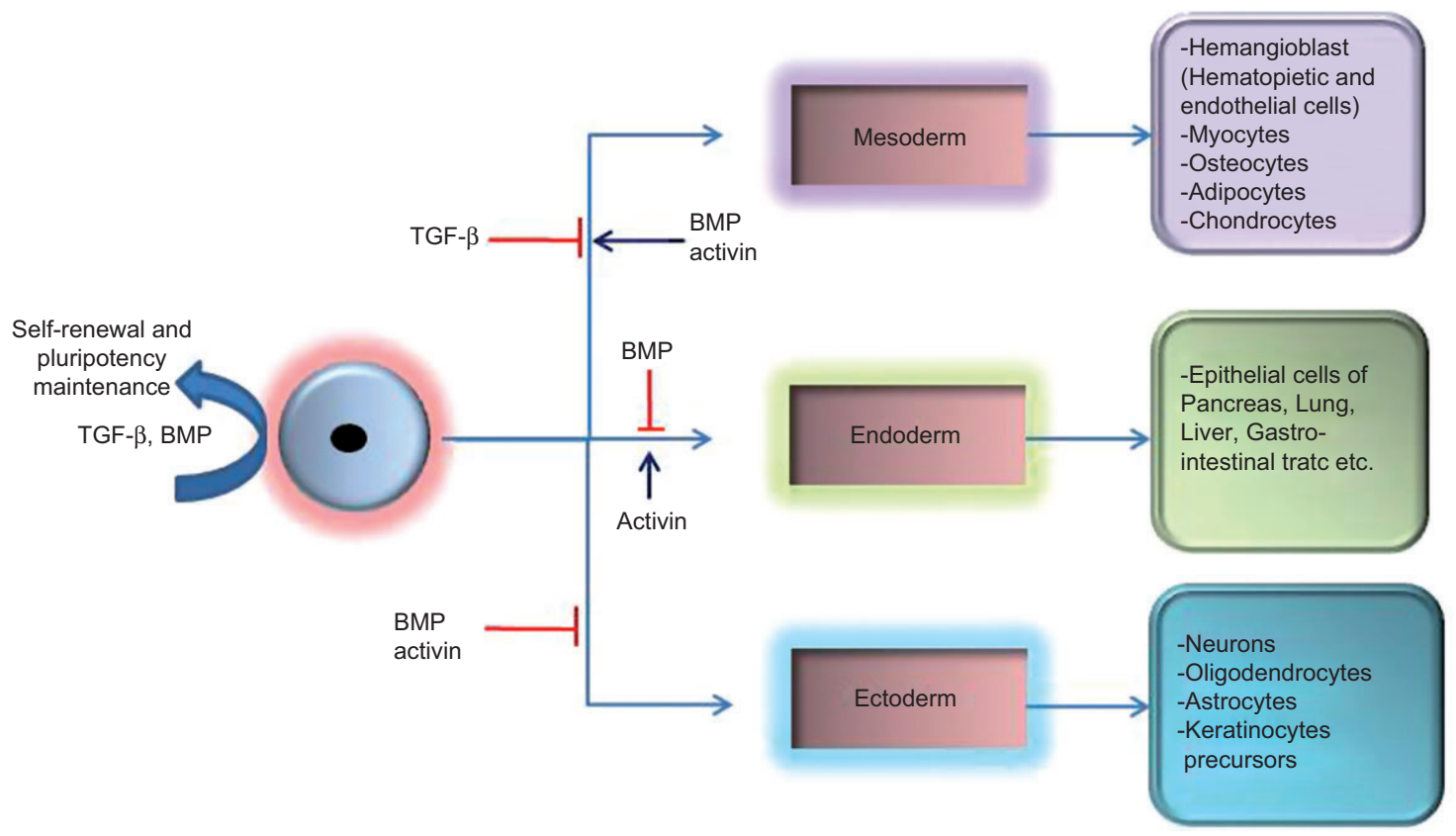

Figure 3 Role of the TGF- $\beta$ superfamily in ESC germ layer specification and maintenance. Adapted from (78).

express Flk1 (vascular endothelial growth factor receptor-2, VEGFR2) and are called hemangioblast (90). In mouse ESCs, BMP4 in combination with VEGF induces hematopoietic differentiation (82). Endothelial differentiation has also been demonstrated in human ESC differentiation under BMP4 treatment $(91,92)$. TGF- $\beta$ inhibited the expression of endodermal, endothelial, and hematopoietic markers in human ESCs, in contrast to mouse ESCs in which TGF- $\beta$ reduced the level of endodermal markers but increased endothelial marker expression (93).

Endodermal derivatives During gastrulation, under the influence of Nodal/Cripto and Wnt, primitive ectoderm cells migrate toward the primitive streak to form mesendoderm and subsequently definitive endoderm (78). Generation of endodermal derivatives from ESCs, as pancreatic and hepatic cells, have opened great expectations for the treatment of type I diabetes and liver diseases, respectively. In mouse ESCs, hepatic differentiation was developed by the treatment with activin alone to define the endoderm committed, and specification progenitors with BMP4, activin, and fibroblast growth factor were followed (94). In addition, the addition of hepatocyte growth factor (HGF), a general hepatotropic cytokine, may guide final maturation of differentiated hepatocytes (95).

Ectodermal derivatives Neural lineages and skin are derived from the ectoderm. ESC-derived ectoderm can give rise to neural (neurons, oligodendrocytes, and astrocytes) and epidermal lineage cells. The neural differentiation of mouse ESCs required the inhibition of BMP signaling in the ectoderm, whereas BMPstimulated the formation of epidermis. Moreover, activation of Nodal signals suppresses neural differentiation from mouse ESCs (96). Interestingly, the dual inhibition of Smads by using a combination of Noggin, a BMP antagonist usually involved in the induction of neural lineages $(97,98)$, and SB431542, a chemical inhibitor of Lefty/activin/TGF- $\beta$ pathways by blocking phosphorylation of the ALK4, ALK5, and ALK7 receptors, promotes neural conversion of human ESCs and induced pluripotent stem cells (99).

Thus, these findings suggest that TGF- $\beta$ family inhibits the commitment of ESCs to neuroectoderm. Interestingly, although BMP signals inhibit neural differentiation at the early gastrula stages, the same signals induce differentiation of neural crest cells at the later stages in embryos (100). These findings show that BMP signals induce the differentiation of multiple types of ectodermic cells in a stage-dependent fashion.

Extensive studies in Xenopus and mouse established the TGF- $\beta$ signaling pathway as a major regulator during embryonic development. More recent studies have demonstrated the importance of this pathway in maintaining pluripotency and self-renewal in human ESCs $(78,101)$.

\section{TGF- $\beta$ superfamily in adult mesenchymal stem cell differentiation}

The TGF- $\beta$ family signaling is of special relevance in cell differentiation of adult MSCs. The TGF- $\beta$ family signaling directs mesenchymal differentiation, e.g., to muscle, bone, cartilage, and fat differentiation, and are important mediators in the maintenance of stem cell pluripotency and the engagement and selection of differentiation pathways. The TGF- $\beta$ ligands are also important in determining the direction and extent of mesenchymal differentiation $(3,79)$.

MSCs are an attractive cell source for application in regenerative medicine due to their excellent proliferation and 
differentiation capacities. MSCs are present in various tissues like bone marrow [bone marrow mesenchymal stem cells (BMMSCs)], adipose tissue, muscle, synovial tissue, liver, dermis, and others (102).

TGF- $\beta$ is considered as a mitogenic factor for MSCs with a role in the maintenance of self-renewal and their undifferentiated and multipotent stem state, although in some conditions, it can induce differentiation. On the other hand, BMPs are considered as differentiation factors due to their capacity to induce MSC differentiation and/or redirect the differentiation commitment of MSCs $(3,79)$.

Human MSCs derived from bone marrow can be expanded more than a billion-fold in culture without losing their stem cell capacity. However, as the molecular mechanisms governing proliferation and differentiation of MSCs are not fully understood, their practical use is currently limited (79).

Next, we will describe the role of the TGF- $\beta$ superfamily in differentiation toward myogenesis, chondrogenesis, osteogenesis, and adipogenesis of adult MSCs (Figure 4).

Myogenesis Skeletal muscle cells differentiate from uncommitted mesenchymal cells through a complex set of differentiation steps that involve commitment to the myoblast lineage, progression of differentiation with expression of muscle cell-specific proteins, and fusion of myoblasts into multinucleated myocytes or myofiber (103, 104). TGF- $\beta$ has been shown as a potent inhibitor of myogenic differentiation. TGF- $\beta$ inhibits myotube formation without affecting cell proliferation or inducing osteoblastogenesis. It has been demonstrated that TGF- $\beta$ inhibits muscle formation via direct interaction of $\mathrm{Smad} 3$ with $\mathrm{MyoD}$ transcription factor $(105,106)$. Myostatin/growth development factor 8 (GDF-8), which is expressed in the myotome layer during development and then is primarily expressed in muscle cells, strongly negatively regulates muscle differentiation (107). Targeted deletion of the GDF- 8 gene in mice provokes both hypertrophy and hyperplasia of muscle fibers resulting in a $>200 \%$ increase in skeletal-muscle mass (107). Consistent with these phenotypes, myostatin inhibits the proliferation and differentiation of myoblasts, and Gdf8-/- myoblasts and satellite cells (muscle progenitor cells interspersed between myofibers) proliferate and differentiate more rapidly than wild-type cells (3). Similar to TGF- $\beta$, GDF8 exerts its effect in myogenesis through Smad3-dependent intracellular signaling cascade $(107,108)$.

Interestingly, BMPs are also potent inhibitory molecules of myogenesis, but conversely to TGF- $\beta$ and GDF8, they provoke growth inhibition accompanied with differentiation toward osteoblast lineage $(3,105)$. BMP signaling activates the expression of inhibitor of DNA binding 1 (Id1), and Id1

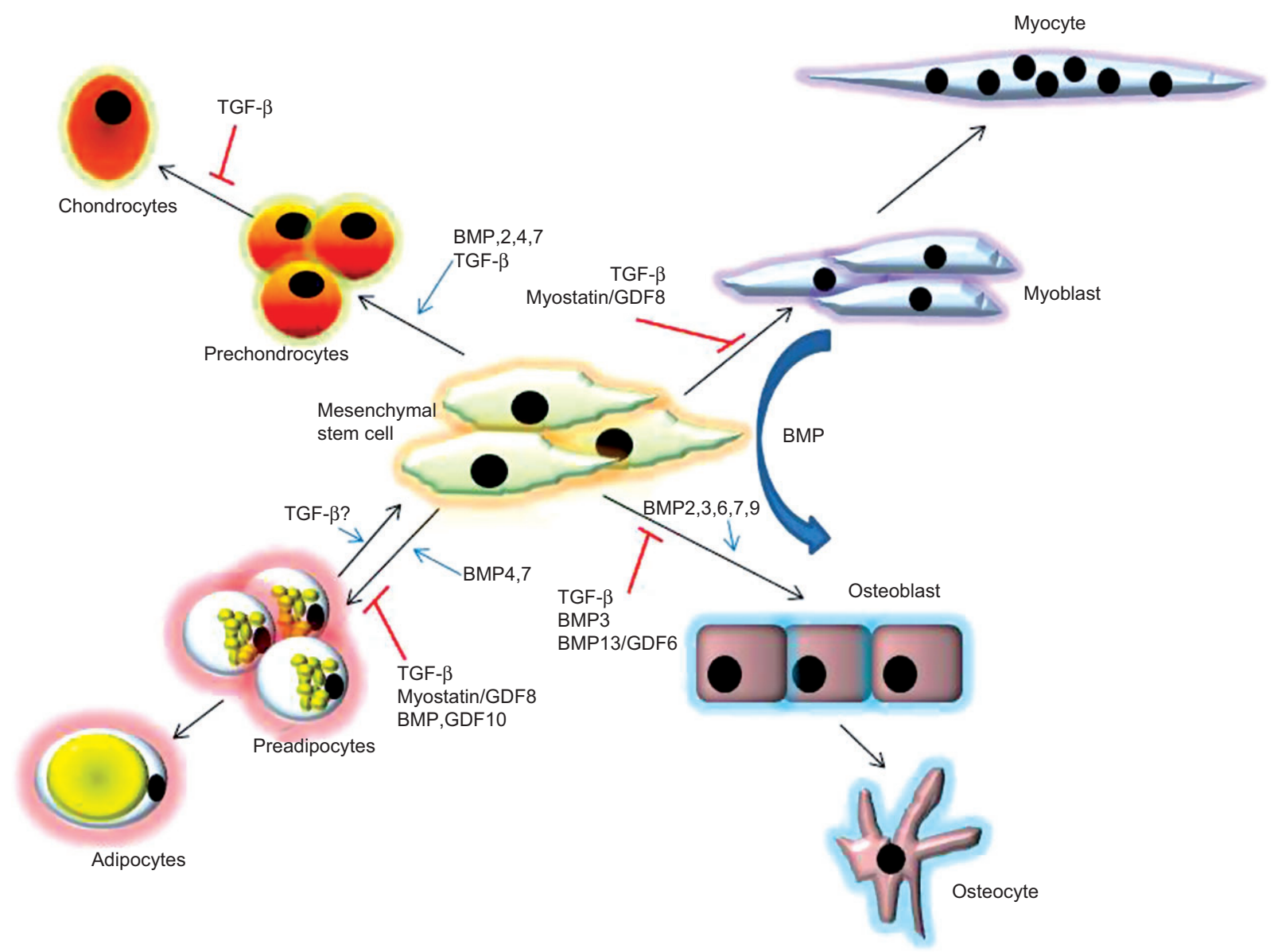

Figure 4 Role of the TGF- $\beta$ superfamily in MSCs differentiation. Adapted from (3). 
inhibits the activity of myogenic basic helix-loop-helix transcription factors (3). After intramuscular injection of BMP, ectopic cartilage and bone tissue is formed, and in this context, it is thought that BMP induces satellite cells and myogenic precursors to differentiate into chondrocytes or osteoblasts (109). Intriguingly, BMP4 is secreted by myogenic precursor cells; the secreted BMP4 is functional and induces the expression of BMP targets Id1 and Id3 $(110,111)$.

Inappropriate BMP signaling, resulting in ectopic osteogenesis may also provide the cellular basis for fibrodysplasia ossificans progressiva, a rare genetic disorder of connective tissue characterized by progressive postnatal endochondral ossification of tendons, ligaments, fascia, and striated muscle. In affected individuals, osteogenic lesions often arise spontaneously, but they can also be induced by surgery, trauma, or intramuscular injections (3). Some evidence suggests that increased BMP signaling is at the basis of this disease as a result of either increased BMP4 expression (111) or caused by activating mutation in the BMP receptor ALK-2 gene (2).

Chondrogenesis Cartilage formation is a strictly regulated process. Differentiation of pre-chondrocytes into differentiated chondrocytes involves a chondroblast phase characterized by high cell proliferation and deposition of cartilage-specific molecules, such as type II collagen and aggrecan. The stage of differentiated chondrocytes is in the growth plate followed by chondrocyte terminal differentiation and endochondral ossification (112).

TGF- $\beta$ plays a role in all phases of chondrogenesis, mesenchymal condensation, chondrocyte proliferation, extracellular matrix deposition, and finally in terminal differentiation. TGF- $\beta$ is the key initiator of chondrogenesis by mesenchymal precursor cells (112). In the early stages of chondrocyte differentiation, TGF- $\beta$ appears to be mainly a stimulator. However, this is in contrast with the actions of this growth factor in the late stages of chondrocyte differentiation, when TGF- $\beta$ inhibits chondrocyte terminal differentiation. TGF- $\beta$ has been shown to stabilize the phenotype of the prehypertrophic chondrocytes (113). Withdrawal of TGF- $\beta$ from the culture medium is essential to further differentiate human MSCs to hypertrophic chondrocytes (114). TGF- $\beta$ treatment initiates and maintains chondrogenesis of mesenchymal precursor cells through the stimulatory activities on MAPKs and modulation of Wnt signaling (115). Conversely, Smad signaling seems to be essential for the inhibition of terminal differentiation of chondrocytes by TGF- $\beta$ (116).

Chondrogenic differentiation in vitro is often achieved in three-dimensional or in high-density culture conditions, in a defined serum-free medium containing TGF- $\beta$ s to express the chondrogenic potential of MSCs. TGF- $\beta 2$ and $-\beta 3$ have been known to be superior to TGF- $\beta 1$ in promoting chondrogenesis, as is achieved by higher accumulation of glycosaminoglycans $(117,118)$.

The BMPs also modulate MSC chondrogenesis; they can induce or enhance differentiation by synergizing with other growth factors and cytokines (119). In combination with TGF$\beta 3$, BMP2 was shown to be more effective to enhance MSC chondrogenesis than BMP4 and -6 (120). Short treatment of MSCs with BMP2 stimulated Runt-related transcription factor 2 (Runx2) and osteopontin expression. Interestingly, chondrogenic differentiation induced by BMP2 was inhibited by TGF- $\beta 1$ co-treatment, suggesting that an appropriate combination of treatment between TGF- $\beta$ family members might achieve a proper differentiation phenotype $(119,121)$.

BMP4 stimulates chondrogenesis, both in vitro and in vivo and is a potential therapeutic agent for cartilage regeneration. The use of BMP4 can successfully induce chondrogenesis in vitro in both embryonic and adult stem cell populations derived from bone marrow, periosteum, adipose tissue, and muscle, particularly in a three-dimensional pellet culture system (122). It has recently been reported that BMP7 can also induce the differentiation of BMMSCs into cartilage cells (123).

Osteogenesis Osteogenesis is a well-orchestrated set of cellular processes, which are strictly directed by various soluble factors such as cytokines and extracellular matrix molecules (116). The in vitro osteogenic differentiation of MSCs is achieved using $\beta$-glycerophosphate as a soluble component of the culture medium (124). A monolayer of MSCs cultured in serum-rich medium containing $\beta$ glycerophosphate and ascorbic acid-2-phosphate exhibits an upregulation of alkaline phosphatase (ALP) activity and deposition of mineralized matrix (124).

TGF- $\beta$ has been reported to exhibit both positive and negative effects on bone differentiation. Exogenously injected TGF- $\beta$ induced bone formation in periosteum $(125,126)$, whereas transgenic mice overexpressing TGF- $\beta 2$ in bone exhibited an osteoporotic phenotype characterized by increased activities of osteoblasts and osteoclasts and impaired matrix mineralization by osteoblasts (127); TGF- $\beta$ inhibits osteoblast differentiation through modulation of the expression and transcriptional activity of Runx2 (128). Conversely, TGF- $\beta$ cooperates with Wnt signaling and promotes osteogenesis of human MSCs. Knockdown of $\beta$-catenin with siRNA stimulated ALP activity and antagonized the inhibitory effects of TGF- $\beta 1$ on bone sialoprotein expression. TGF- $\beta 1$ activates $\beta$-catenin signaling via ALK5, Smad3, PKA, and PI3K pathways and modulates osteoblastogenesis via ALK5, PKA, and JNK pathways in human MSCs (129).

BMPs, especially BMP2, BMP4 BMP6, BMP7, and BMP9, have been shown to enhance osteogenic differentiation of MSCs $(21,130)$. Recombinant human BMP2 and BMP7 are used clinically to augment bone formation in spinal fusion and many other applications in which bone induction is desired $(2,131)$. BMP6 circulates in the normal human plasma and is produced by BM-MSCs prior to differentiation into osteoblasts (132). BMP7 induced the expression of osteoblastic differentiation markers such as ALP activity and accelerated calcium mineralization (133). Wnt3A and BMP9 enhanced each other's ability to induce ALP in MSCs. Interactions between $\beta$-catenin and Runx2 play an important role in BMP9-induced osteogenic differentiation of MSCs (133).

Contrary to other BMPs, BMP3 and BMP 13/GDF6 have been shown to inhibit bone formation. BMP3, by inhibiting 
the activity of BMP2, has been suggested as useful for the treatment of osteopetrosis and other diseases characterized by bone hypermineralization, while BMP13 demonstrated deceleration of calcium mineralization of the extracellular matrix and reduced ALP induction in BMMSCs $(122,134)$.

Interestingly, inhibition of TGF- $\beta$ signaling by the small chemical inhibitor SB431542 promotes osteoblastic differentiation of MSCs induced by BMP-4, suggesting that inhibition of endogenous TGF- $\beta$ signaling with activated BMP signaling directs differentiation of human MSCs to osteoblasts (135). However, TGF- $\beta 1$ was shown to enhance BMP2-induced ectopic bone formation, probably by the increment of BMP receptor BMPR-IB/ALK6 as suggested by in vitro studies (136). These observations indicate a strong and intricate interplay between TGF- $\beta$ and BMP signaling in osteoblast differentiation (133).

Finally, the pharmacological inhibition of Rho-ROCK1 enhances BMP induction of osteogenesis both in vivo and in vitro, suggesting its clinical applicability for stimulating bone formation (137).

Adipogenesis Adipocytes arise from MSCs, originally derived from pluripotent ESCs. Progenitor cells do not accumulate lipids but express the transcription factor peroxisome proliferator-activated receptor $\gamma(\operatorname{PPAR} \gamma)$, an early marker and key modulator of adipogenesis. Adipogenic differentiation of mesenchymal cells into fully differentiated adipocytes is driven by the cooperation of PPAR $\gamma$ with Ccaatenhancer-binding proteins $(\mathrm{C} / \mathrm{EBP} \alpha)$ to express proteins that allow adipocyte differentiation, including those involved in lipid drop cytoplasmic accumulation (138-140).

TGF- $\beta 1$ exerts a great influence in adipogenesis (140). In vitro studies show that TGF- $\beta 1$ inhibits the early stages of 3T3-L1 (mouse cells that resemble preadipocytes) differentiation into mature adipocytes (141), promotes the proliferation of progenitor cells (142), and hampers lipid accumulation (143). The inhibition of differentiation by TGF- $\beta 1$ is mainly mediated by Smad3. Increased activity of Smad3 inhibits adipogenic conversion, whereas interfering with Smad3 function enhances and accelerates adipose conversion in culture and confers resistance to inhibition of adipogenic differentiation by TGF- $\beta(3,103$, and 142$)$.

The effects of BMPs on adipogenesis appear to depend on the stage of cell development and the dosage of different BMP ligands $(141,144)$. BMP2 was shown to inhibit adipocyte differentiation of bone marrow stroma cell lines and 3T3-F442A preadipocyte cells, while stimulating adipogenesis in 3T3-L1 preadipocyte cells by induction of PPAR $\gamma$ mainly mediated by Smad-1/5/8 and p38 signal pathways $(145,146)$. This discrepancy may relate to differences in cell systems and/or culture conditions, for example, relative levels of ligand for PPAR $\gamma$, the central transcription factor in the adipocyte differentiation pathway, in the culture medium (145). Adipogenic effects of BMP2 are mediated by the transcriptional coactivator Schnurri-2 (Shn-2). In experiments with Shn-2-null mice and consequently reduced BMP2 signaling, there was a poor differentiation of embryo fibroblasts into adipocytes and reduced adipose mass. Upon BMP2 treatment, Shn-2, in cooperation with Smad1/4 and C/EBP $\alpha$, induced the expression of PPAR $\gamma 2$, a key transcription factor for adipocyte differentiation (147). BMP4 promotes MSC commitment to the adipose lineage and induces adipogenesis in a dose-dependent manner. This was demonstrated by treating C3H10T1/2 cells with recombinant human BMP4 (148). BMP3 is known as a negative regulator of osteogenesis. In vitro models revealed that BMP3 stimulates the proliferation of both C3H10T1/2 and 3T3-L1 preadipocytes via the TGF- $\beta /$ activin pathway, while it does not promote the commitment of MSCs or the differentiation of preadipocytes (149). BMP7 via $\mathrm{p} 38$ MAPK activates a full program of brown adipogenesis including increased expression of UCP-1, C/EBPs, and PPAR $\gamma$ and blockade of adipogenic inhibitors such as necdin, preadipocyte factor-1 (Pref-1), and Wnt10a. It also induces early modulators of adipogenesis, such as PPAR $\gamma$ coactivator 1 (PGC-1) and mitochondrial biogenesis (140, 150). In vivo, the BMP7-expressing adenoviruses injection significantly increased brown adipose tissue, concomitantly with an increase in energy expenditure and weight loss. Conversely, BMP7 knockout mice developed 50-70\% less brown adipose tissue. BMP7 was shown to induce the generation of brown, but not white, adipose tissue from MSCs in the absence of the normally required hormonal induction cocktail (150).

GDF8/myostatin competitively inhibits BMP7 and blocks the expression of late differentiation markers (151). MSCs in mice treated with GDF8 exhibit a gene profile consistent with immature adipocytes, with increased insulin sensitivity, glucose oxidation, and resistance to diet-induced obesity (152). GDF8 inhibits MSCs and preadipocyte differentiation through Smad3 (153). BMP3b/GDF10 suppresses adipogenesis in 3T3-L1 cells. Studies in these cells demonstrated that BMP3b/GDF10 is expressed at higher levels in preadipocytes than in mature adipocytes. Knockdown of endogenous BMP3b/GDF10 enhances adipogenesis, while addition of exogenous BMP3b/GDF10 inhibits adipocyte differentiation by suppressing the expression of PPAR $\gamma$ and C/EBPs. Also, the increased levels of BMP3b/GDF10 in mesenteric adipose tissue of mice in diet-induced obesity indicate that BMP3b/ GDF10 may function as a feedback mechanism to inhibit adipogenesis in abdominal obesity (154).

In addition to their effect on MSCs, BMPs can also redirect cells that have initiated differentiation along the adipogenic lineage to osteoblastic differentiation. This raises the possibility that adipose stroma cells could be used for cell-based therapy in bone repair (3).

It is generally accepted that TGF- $\beta$ inhibits MSC differentiation along the osteoblast, skeletal myoblast, and adipocyte lineages and stimulates the proliferation and maintenance of stem cells, whereas BMPs stimulate the selection and progression of differentiation along defined mesenchymal lineages as well as redirection of MSCs differentiation toward bone, i.e., inhibiting myogenesis or adipogenesis differentiation and redirecting cells toward the osteoblast lineage.

Interestingly, TGF- $\beta$ is a potent inductor of epithelialmesenchymal transition (EMT), a biological process that allows a polarized epithelial cell to undergo multiple biochemical changes that enable it to assume a mesenchymal 
cell phenotype (155). EMT has been associated with embryo implantation, embryogenesis, and organ development, as well as chronic inflammation, organ fibrosis, and cancer. Recently, it has been described that EMT-derived cells also have a functional resemblance to MSCs derived from human bone marrow, including a similar antigenic phenotype and the ability to differentiate into multiple cell lineages (156). This process can be antagonized by BMP, as demonstrated in mouse models of fibrosis (155). In addition, TGF- $\beta$ can induce endothelial cells associated with microvasculature to contribute to the formation of mesenchymal cells, through the endothelial mesenchymal transition (ENdMT), process that can occur during pathological situations and during development as well $(155,157)$. However, the EndMT-derived mesenchymal cell ability to differentiate into different lineages, like MSCs, remains to be elucidated. Future studies may consider using the EMT and EndMT cellular processes, by modulating TGF- $\beta$, in the development of therapeutics aimed at the regeneration of damaged tissues. However, as these processes are also involved in pathological circumstances, several cautions are necessary to be considered prior to future use in regenerative medicine.

\section{Expert opinion}

The biology of both embryonic stem and adult MSCs has opened new avenues and tremendous expectations both in the biology of development of human diseases and in tissue engineering for regenerative medicine. From the last two decades, an increasing number of laboratories are making efforts to reveal the biochemical, molecular, and cellular regulatory mechanisms that underlie the renewal and differentiation of stem cells. It is now established that TGF- $\beta$ superfamily members participate in almost all steps of the fate decision of stem cells. The family comprises a variety of growth factors that feature disparate functions in the biology of ESCs. These factors regulate both the maintenance of stem cells in their undifferentiated and multipotent stem state, 'stemness' (158), and various cell differentiation pathways. The remarkable efforts made by researches using a combination of cellular and molecular systems have contributed to our current knowledge of the modulatory mechanisms that provide the diversity of TGF- $\beta$ signaling system. Using this information, we will be able to control stem cell growth, differentiation, expansion, and plasticity, which in combination with other growth factors and cytokines may improve cellular therapy and regenerative medicine for human diseases. Although extraordinary advances in the understanding of TGF- $\beta$ signaling have been done, it is still necessary to specify the individual role of many of the members of the family, as well as the transcriptional activities triggered by Smad and nonSmad pathways in the maintenance of 'stemness.' In addition, TGF- $\beta$ /BMP pathways have now been shown to directly influence microRNA (miRNA) biogenesis to mediate substantial cellular phenotypes (159). The miRNAs are crucial for selfrenewal and behavior of ESCs and MSCs $(160,161)$. This opened a new line of studies and expanded the possibilities for the understanding of the regulation of stem cell function and fate by the TGF- $\beta$ superfamily.

High-throughput drug screening has been used to find chemical compounds that selectively regulate the TGF- $\beta$ family system, and some of them are currently being used in clinical trials to treat TGF- $\beta$-implicated human diseases. A crucial discovery of new compounds with high specificity has made it possible to finely target TGF- $\beta$ s expression, receptor binding and kinase activities, intracellular signal transduction and gene transcription to modulate the TGF- $\beta$ family effects on stem cell biology and differentiation. This may allow the development of new therapeutic approaches for the treatment of diseases involving cellular, tissue, and organic disorders. Such are developmental diseases and degenerative disorders: muscular dystrophy, arthritis, which could be treated by fomenting new cartilage formation; osteoporosis, by preventing bone loss and stimulating local osteogenesis; obesity, by stimulating brown adipose differentiation or preventing white adipose tissue formation, among a number of other impairments and conditions. Also, by controlling the TGF- $\beta$ activities, it might be possible to drive stem cell differentiation to produce desirable cell types, tissues, and organs to use in tissue engineering for regenerative medicine and to improve human health and quality of life. Considering the number of members of the TGF- $\beta$ superfamily, their receptors, different signaling pathways, as well as the possibilities to exploit this superfamily in the use of stem cells in all states of human body development and in a number of diseases, an integration of all statements of biology, medicine, and bioengineering is essential to address different questions and to gain understanding for the use of stem cells and the TGF- $\beta$ superfamily in the treatment of diseases and human body regeneration.

\section{Outlook}

Although it is difficult to predict the ultimate utility of stem cell-based therapy, it is possible to speculate that by manipulating the TGF- $\beta$ superfamily system and in concordance with other growth factors, cytokines, and surgical regulation of intracellular signaling and gene expression, it may be that the future will hold a revolutionary new medicine in the form of specific on-demand MSC cell therapies for particular human diseases and regenerative medicine.

\section{Highlights}

- The members of the TGF- $\beta$ superfamily are implicated in morphogenesis, embryonic development, MSC differentiation, immune regulation, wound healing, inflammation, and cancer.

- The TGF- $\beta$ superfamily of secreted growth factors comprises more than 40 ligands including TGF- $\beta$ s, BMPs, GDFs, and MIFs.

- The TGF- $\beta$ superfamily members bind to their cell surface receptors to form heteromeric complexes. Dimers of type I (ALK1-7) and type II receptors (TGFBR2, BMPR2, 
ACVR2, ACVR2B, and AMHR2) serine/threonine kinase receptors interact with the dimeric ligands.

- The TGF- $\beta$ superfamily-activated receptor complexes transduce intracellular signaling by the type I receptor phosphorylation of Smads in their carboxy-terminal domains. The TGF- $\beta$ /activin branch signals to the nucleus mainly through Smad 2, 3, and the BMP/GDF branch signals through Smad 1, 5, and 8.

- TGF- $\beta$ and BMP activate intracellular signaling named as non-Smad pathways, such as ERK1, 2, p38, and JNK MAPKs.

- The TGF- $\beta$ superfamily members are key players in the self-renewal and maintenance of ESCs and somatic stem cells in their undifferentiated state, the selection of cell fate, and the progression of differentiation along a lineage.

- The TGF- $\beta$ ligands play an important role in the selfrenewal, maintenance, and regulation of differentiation of ESCs. Differentiation of the three germ layers (mesoderm, endoderm, and ectoderm) from ESCs is regulated by a combination of the TGF- $\beta$ superfamily ligands.

- TGF- $\beta$ is considered as a mitogenic factor for MSCs with a role in the maintenance of self-renewal of MSCs, although in some conditions, it can induce differentiation. On the other hand, BMPs are considered as differentiation factors due to their capacity to induce MSC differentiation and/or redirect the differentiation commitment of MSCs.

- TGF- $\beta$ is a potent inductor of EMT, a biological process that allows differentiated cells to undergo multiple biochemical changes that enable them to assume a mesenchymal cell phenotype, similar to MSCs derived from human bone marrow, including a similar antigenic phenotype and the ability of differentiation into multiple cell lineages. The EMT process can be antagonized by BMPs. These findings propose EMT as a new way and source to produce MSCs for use in regenerative medicine.

- It is necessary to specify the individual role of many of the members of the TGF- $\beta$ family, as well as the transcriptional activities triggered by Smad and non-Smad pathways in the maintenance of 'stemness' of MSCs.

- The modulation of microRNA biogenesis by the TGF- $\beta$ superfamily members opened a new line of studies and expanded the possibilities for the understanding of the regulation of stem cell function and fate.

\section{Acknowledgements}

We acknowledge the contributions of many researchers that, although relevant to the issues dealt with in the present review, could not be included due to space limitations. This work was supported by grant number 175062 of the Ministry of Science and Technological Development, Republic of Serbia.

\section{References}

1. Gordon KJ, Blobe GC. Role of transforming growth factor- $\beta$ superfamily signaling pathways in human disease. Biochim Biophys Acta 2008; 1782: 197-228.
2. Santibañez JF, Quintanilla M, Bernabeu C. TGF- $\beta$ /TGF- $\beta$ receptor system and its role in physiological and pathological conditions. Clin Sci (Lond) 2011; 121: 233-51.

3. Derynck R, Akhurst RJ. Differentiation plasticity regulated by TGF- $\beta$ family proteins in development and disease. Nat Cell Biol 2007; 9: 1000-4.

4. Horbelt D, Denkis A, Knaus P. A portrait of transforming growth factor $\beta$ superfamily signalling: background matters. Int $\mathrm{J}$ Biochem Cell Biol 2012; 44: 469-74.

5. Galat A. Common structural traits for cystine knot domain of the TGF $\beta$ superfamily of proteins and three-fingered ectodomain of their cellular receptors. Cell Mol Life Sci 2011; 68: 3437-51.

6. Anzano MA, Roberts AB, Smith JM, Sporn MB, De Larco JE. Sarcoma growth factor from conditioned medium of virally transformed cells is composed of both type alpha and type beta transforming growth factors. Proc Natl Acad Sci USA 1983; 80: 6264-8.

7. Govinden R, Bhoola KD. Genealogy, expression, and cellular function of transforming growth factor- $\beta$. Pharmacol Ther 2003; 98: $257-65$

8. Birchenall-Roberts MC, Ruscetti FW, Kasper J, Lee HD, Friedman R, Geiser A, Sporn MB, Roberts AB, Kim SJ. Transcriptional regulation of the transforming growth factor beta 1 promoter by $\mathrm{v}$-src gene products is mediated through the AP-1 complex. Mol Cell Biol 1990; 10: 4978-83.

9. Dey BR, Sukhatme VP, Roberts AB, Sporn MB, Rauscher FJ 3rd, Kim SJ. Repression of the transforming growth factor-beta 1 gene by the Wilms' tumor suppressor WT1 gene product. Mol Endocrinol 1994; 8: 595-602.

10. Lafyatis R, Lechleider R, Kim SJ, Jakowlew S, Roberts AB, Sporn MB. Structural and functional characterization of the transforming growth factor beta 3 promoter. A cAMP-responsive element regulates basal and induced transcription. J Biol Chem 1990; 265: 19128-36.

11. O'Reilly MA, Geiser AG, Kim SJ, Bruggeman LA, Luu AX, Roberts AB, Sporn MB. Identification of an activating transcription factor (ATF) binding site in the human transforming growth factor-beta 2 promoter. J Biol Chem 1992; 267: 19938-43.

12. Roberts AB. Molecular and cell biology of TGF-beta. Miner Electrolyte Metab 1998; 24: 111-9.

13. Rifkin DB. Latent transforming growth factor-beta (TGF-beta) binding proteins: orchestrators of TGF-beta availability. J Biol Chem 2005; 280: 7409-12.

14. Dubois CM, Laprise MH, Blanchette F, Gentry LE, Leduc R. Processing of transforming growth factor beta 1 precursor by human furin convertase. J Biol Chem 1995; 270: 10618-24.

15. Chaudhry SS, Cain SA, Morgan A, Dallas SL, Shuttleworth CA, Kielty CM. Fibrillin-1 regulates the bioavailability of TGFbeta1. J Cell Biol 2007; 176: 355-67.

16. Crawford SE, Stellmach V, Murphy-Ullrich JE, Ribeiro SM, Lawler J, Hynes RO, Boivin GP, Bouck N. Thrombospondin-1 is a major activator of TGF-betal in vivo. Cell 1998; 93 : 1159-70.

17. Yu Q, Stamenkovic I. Cell surface-localized matrix metalloproteinase-9 proteolytically activates TGF-beta and promotes tumor invasion and angiogenesis. Genes Dev 2000; 14: 163-76.

18. Munger JS, Harpel JG, Gleizes PE, Mazzieri R, Nunes I, Rifkin DB. Latent transforming growth factor-beta: structural features and mechanisms of activation. Kidney Int 1997; 51: 1376-82.

19. Urist MR, Strates BS. Bone morphogenetic protein. J Dent Res 1971; 50: 1392-406. 
20. Katagiri T, Suda T, Miyazono K. The bone morphogenetic proteins in the TGF-B family. In: Derynck R, Miyazono K, editors. The TGF-beta family. New York: Cold Spring Harbor Laboratory Press, 2008: 121-49.

21. Miyazono K, Kamiya Y, Morikawa M. Bone morphogenetic protein receptors and signal transduction. J Biochem 2010; 147: $35-51$.

22. Hearn MT, Gomme PT. Molecular architecture and biorecognition processes of the cystine knot protein superfamily: part I. The glycoprotein hormones. J Mol Recognit 2000; 13: 223-78.

23. Yanagita M. BMP modulators regulate the function of BMP during body patterning and disease progression. Biofactors 2009; 35: 113-9.

24. Rider CC, Mulloy B. Bone morphogenetic protein and growth differentiation factor cytokine families and their protein antagonists. Biochem J 2010; 429: 1-12.

25. Lin J, Patel SR, Cheng X, Cho EA, Levitan I, Ullenbruch M, Phan SH, Park JM, Dressler GR. Kielin/chordin-like protein, a novel enhancer of BMP signaling, attenuates renal fibrotic disease. Nat Med 2005; 11: 387-93.

26. Ikeya M, Kawada M, Kiyonari H, Sasai N, Nakao K, Furuta Y, Sasai Y. Essential pro-Bmp roles of crossveinless 2 in mouse organogenesis. Development 2006; 133: 4463-73.

27. Bragdon B, Moseychuk O, Saldanha S, King D, Julian J, Nohe A. Bone morphogenetic proteins: a critical review. Cell Signal 2011; 23: 609-20.

28. Katoh Y, Katoh M. Comparative integromics on BMP/GDF family. Int J Mol Med 2006; 17: 951-5.

29. Visser JA, de Jong FH, Laven JS, Themmen AP. Anti-Müllerian hormone: a new marker for ovarian function. Reproduction 2006; 131: 1-9.

30. di Clemente N, Josso N, Gouédard L, Belville C. Components of the anti-Müllerian hormone signaling pathway in gonads. Mol Cell Endocrinol 2003; 211: 9-14.

31. Xia Y, Schneyer AL. The biology of activin: recent advances in structure, regulation and function. J Endocrinol 2009; 202: $1-12$.

32. Lin SJ, Lerch TF, Cook RW, Jardetzky TS, Woodruff TK. The structural basis of TGF-beta, bone morphogenetic protein, and activin ligand binding. Reproduction 2006; 132: 179-90.

33. Stenvers KL, Findlay JK. Inhibins: from reproductive hormones to tumor suppressors. Trends Endocrinol Metab 2010; 21 : 174-80.

34. Nickel J, Sebald W, Groppe JC, Mueller TD. Intricacies of BMP receptor assembly. Cytokine Growth Factor Rev 2009; 20 : 367-77.

35. Ehrlich M, Gutman O, Knaus P, Henis YI. Oligomeric interactions of TGF- $\beta$ and BMP receptors. FEBS Lett 2012; 586: 1885-96.

36. Ehrlich M, Horbelt D, Marom B, Knaus P, Henis YI. Homomeric and heteromeric complexes among TGF-beta and BMP receptors and their roles in signaling. Cell Signal 2011; 23: 1424-32.

37. Bernabeu C, Lopez-Novoa JM, Quintanilla M. The emerging role of TGF-beta superfamily coreceptors in cancer. Biochim Biophys Acta 2009; 1792: 954-73.

38. Souchelnytskyi S, ten Dijke P, Miyazono K, Heldin $\mathrm{CH}$. Phosphorylation of Ser165 in TGF-beta type I receptor modulates TGF-beta1-induced cellular responses. EMBO J 1996; 15: 6231-40.

39. Huse M, Chen YG, Massagué J, Kuriyan J. Crystal structure of the cytoplasmic domain of the type I TGF beta receptor in complex with FKBP12. Cell 1999; 96: 425-36.
40. Huse M, Muir TW, Xu L, Chen YG, Kuriyan J, Massagué J. The TGF beta receptor activation process: an inhibitor- to substratebinding switch. Mol Cell 2001; 8: 671-82.

41. Kang JS, Liu C, Derynck R. New regulatory mechanisms of TGF-beta receptor function. Trends Cell Biol 2009; 19: 385-94.

42. Shi W, Sun C, He B, Xiong W, Shi X, Yao D, Cao X. GADD34PP1c recruited by Smad7 dephosphorylates TGFbeta type I receptor. J Cell Biol 2004; 164: 291-300.

43. Satow R, Kurisaki A, Chan T-C, Hamazaki TS, Asashima M. Dullard promotes degradation and dephosphorylation of BMP receptors and is required for neural induction. Dev Cell 2006; 11 : 763-74.

44. Wang Y, Dasso M. SUMOylation and deSUMOylation at a glance. J Cell Sci 2009; 122: 4249-52.

45. Kang JS, Saunier EF, Akhurst RJ, Derynck R. The type I TGFbeta receptor is covalently modified and regulated by sumoylation. Nat Cell Biol 2008; 10: 654-64.

46. Di Guglielmo GM, Le Roy C, Goodfellow AF, Wrana JL. Distinct endocytic pathways regulate TGF-beta receptor signalling and turnover. Nat Cell Biol 2003; 5: 410-21.

47. Kavsak P, Rasmussen RK, Causing CG, Bonni S, Zhu H, Thomsen GH, Wrana JL. Smad7 binds to Smurf2 to form an E3 ubiquitin ligase that targets the TGF $\mathrm{b}$ receptor for degradation. Mol Cell 2000; 6: 1365-75.

48. Ebisawa T, Fukuchi M, Murakami G, Chiba T, Tanaka K, Imamura T, Miyazono K. Smurf1 interacts with transforming growth factor-b type I receptor through Smad7 and induces receptor degradation. J Biol Chem 2001; 276: 12477-80.

49. Chang H, Brown CW, Matzuk MM. Genetic analysis of the mammalian transforming growth factor-beta superfamily. Endocr Rev 2002; 23: 787-823.

50. Shi Y, Massagué J. Mechanisms of TGF-beta signaling from cell membrane to the nucleus. Cell 2003; 113: 685-700.

51. Tsukazaki T, Chiang TA, Davison AF, Attisano L, Wrana JL. SARA, a FYVE domain protein that recruits $\operatorname{Smad} 2$ to the TGFbeta receptor. Cell 1998; 95: 779-91.

52. Attisano L, Lee-Hoeflich ST. The Smads. Genome Biol 2001; 2 : REVIEWS3010.

53. Zhang Y, Feng X, We R, Derynck R. Receptor-associated Mad homologues synergize as effectors of the TGF-beta response. Nature 1996; 383: 168-72.

54. Itoh S, ten Dijke P. Negative regulation of TGF-beta receptor/Smad signal transduction. Curr Opin Cell Biol 2007; 19: 176-84.

55. Massague J, Chen YG. Controlling TGF-B signaling. Genes Dev 2000; 14: 627-44.

56. Miyazono K, Maeda S, Imamura T. BMP receptor signaling: transcriptional targets, regulation of signals, and signaling crosstalk. Cytokine Growth Factor Rev 2005; 16: 251-63.

57. Morikawa M, Koinuma D, Tsutsumi S, Vasilaki E, Kanki Y, Heldin CH, Aburatani H, Miyazono K. ChIP-seq reveals cell type-specific binding patterns of BMP-specific Smads and a novel binding motif. Nucleic Acids Res 2011; 39: 8712-27.

58. Zhang YE. Non-Smad pathways in TGF-beta signaling. Cell Res 2009; 19: 128-39.

59. Mulder KM, Morris SL. Activation of p21ras by transforming growth factor beta in epithelial cells. J Biol Chem 1992; 267: 5029-31.

60. Lee MK, Pardoux C, Hall MC, Lee PS, Warburton D, Qing J, Smith SM, Derynck R. TGF-beta activates Erk MAP kinase signalling through direct phosphorylation of ShcA. EMBO J 2007; 26: 3957-67. 
61. Sorrentino A, Thakur N, Grimsby S, Marcusson A, von Bulow V, Schuster N, Zhang S, Heldin CH, Landström M. The type I TGF-beta receptor engages TRAF6 to activate TAK1 in a receptor kinase-independent manner. Nat Cell Biol 2008; 10: 1199-207.

62. Yamashita M, Fatyo K, Jin C, Wang X, Liu Z, Zhang YE. TRAF6 mediates Smad-independent activation of JNK and p38 by TGF- $\beta$. Mol Cell 2008; 31: 918-24.

63. Moustakas A, Heldin CH. Signaling networks guiding epithelialmesenchymal transitions during embryogenesis and cancer progression. Cancer Sci 2007; 98: 1512-20.

64. Xu J, Lamouille S, Derynck R. TGF-beta-induced epithelial to mesenchymal transition. Cell Res 2009; 19: 156-72.

65. Konstantinidis G, Moustakas A, Stournaras C. Regulation of myosin light chain function by BMP signaling controls actin cytoskeleton remodeling. Cell Physiol Biochem 2011; 28: 1031-44.

66. Gamell C, Osses N, Bartrons R, Ruckle T, Camps M, Rosa JL, Ventura F: Bmp2 induction of actin cytoskeleton reorganization and cell migration requires pi3-kinase and cdc42 activity. J Cell Sci 2008; 121: 3960-70.

67. Wilkes MC, Mitchell H, Penheiter SG, Doré JJ, Suzuki K, Edens M, Sharma DK, Pagano RE, Leof EB. Transforming growth factor-beta activation of phosphatidylinositol 3-kinase is independent of Smad2 and Smad 3 and regulates fibroblast responses via p21-activated kinase-2. Cancer Res 2005; 65: 10431-40.

68. Yi JY, Shin I, Arteaga CL. Type I transforming growth factor beta receptor binds to and activates phosphatidylinositol 3-kinase. J Biol Chem 2005; 280: 10870-6.

69. Chen RH, Su YH, Chuang RL, Chang TY. Suppression of transforming growth factor-beta-induced apoptosis through a phosphatidylinositol 3-kinase/Akt-dependent pathway. Oncogene 1998; 17: 1959-68.

70. Song K, Wang H, Krebs TL, Danielpour D. Novel roles of Akt and mTOR in suppressing TGF-beta/ALK5-mediated Smad3 activation. EMBO J 2006; 25: 58-69.

71. James D, Levine AJ, Besser D, Hemmati-Brivanlou A. TGFb/ activin/nodal signaling is necessary for the maintenance of pluripotency in human embryonic stem cells. Development 2005; 132: $1273-82$.

72. Smith AG. Embryo-derived stem cells: of mice and men. Annu Rev Cell Dev Biol 2001; 17: 435-62.

73. Evans M, Kaufman MH. Establishment in culture of pluripotential cells from mouse embryos. Nature 1981; 292: 154-6.

74. Thomson JA, Itskovitz-Eldor J, Shapiro SS, Waknitz MA, Swiergiel JJ, Marshall VS, Jones JM. Embryonic stem cell lines derived from human blastocysts. Science 1998; 282: 1145-7.

75. Wobus AM, Boheler KR. Embryonic stem cells: prospects for developmental biology and cell therapy. Physiol Rev 2005; 85: 635-78.

76. Murry CE, Keller G. Differentiation of embryonic stem cells to clinically relevant populations: lessons from embryonic development. Cell 2008; 132: 661-80.

77. Pucéat M. TGF $\beta$ in the differentiation of embryonic stem cells. Cardiovasc Res 2007; 74: 256-61.

78. Seuntjens E, Umans L, Zwijsen A, Sampaolesi M, Verfaillie CM, Huylebroeck D. Transforming growth factor type beta and Smad family signaling in stem cell function. Cytokine Growth Factor Rev 2009; 20: 449-58.

79. Watabe T, Miyazono K. Roles of TGF- $\beta$ family signaling in stem cell renewal and differentiation. Cell Res 2009; 19: 103-15.

80. Dupont S, Zacchigna L, Cordenonsi M, Soligo S, Adorno M, Rugge M, Piccolo S. Germ-layer specification and control of cell growth by Ectodermin, a Smad4 ubiquitin ligase. Cell 2005; 121: 87-99.

81. Tada S, Era T, Furusawa C, Sakurai H, Nishikawa S, Kinoshita M, Nakao K, Chiba T, Nishikawa S. Characterization of mesendoderm: a diverging point of the definitive endoderm and mesoderm in embryonic stem cell differentiation culture. Development 2005; 132: 4363-74.

82. Park C, Afrikanova I, Chung YS, Zhang WJ, Arentson E, Fong Gh G, Rosendahl A, Choi K. A hierarchical order of factors in the generation of FLK1- and SCL-expressing hematopoietic and endothelial progenitors from embryonic stem cells. Development 2004; 131: 2749-62.

83. Willems E, Leyns L. Patterning of mouse embryonic stem cellderived pan-mesoderm by Activin A/Nodal and Bmp4 signaling requires Fibroblast Growth Factor activity. Differentiation 2008; 76: 745-59.

84. Mahmood A, Harkness L, Schrøder HD, Abdallah BM, Kassem M. Enhanced differentiation of human embryonic stem cells to mesenchymal progenitors by inhibition of TGF-beta/activin/nodal signaling using SB-431542. J Bone Miner Res 2010; 25: 1216-33.

85. Sasai Y, Lu B, Piccolo S, De Robertis EM. Endoderm induction by the organizer-secreted factors chordin and noggin in Xenopus animal caps. EMBO J 1996; 15: 4547-55.

86. D’Amour KA, Agulnick AD, Eliazer S, Kelly OG, Kroon E, Baetge EE. Efficient differentiation of human embryonic stem cells to definitive endoderm. Nat Biotechnol 2005; 23: 1534-41.

87. Laflamme MA, Chen KY, Naumova AV, Muskheli V, Fugate JA, Dupras SK, Reinecke H, Xu C, Hassanipour M, Police S, O'Sullivan C, Collins L, Chen Y, Minami E, Gill EA, Ueno S, Yuan C, Gold J, Murry CE. Cardiomyocytes derived from human embryonic stem cells in pro-survival factors enhance function of infarcted rat hearts. Nat Biotechnol 2007; 25: 1015-24.

88. Behfar A, Zingman LV, Hodgson DM, Rauzier JM, Kane GC, Terzic A, Pucéat M. Stem cell differentiation requires a paracrine pathway in the heart. FASEB J 2002; 16: 1558-66.

89. Yuasa S, Itabashi Y, Koshimizu U, Tanaka T, Sugimura K, Kinoshita M, Hattori F, Fukami S, Shimazaki T, Ogawa S, Okano H, Fukuda K. Transient inhibition of BMP signaling by Noggin induces cardiomyocyte differentiation of mouse embryonic stem cells. Nat Biotechnol 2005; 23: 607-11.

90. Nishikawa ST, Nishikawa S, Hirashima M. Progressive lineage analysis by cell sorting and culture identities FLK1+ VE-cadherin+ cells at a diverging point of endothelial and hematopoietic lineages. Development 1998; 125: 1747-57.

91. Levenberg S, Golub JS, Amit M, Itskovitz-Eldor J, Langer R. Endothelial cells derived from human embryonic stem cells. Proc Natl Acad Sci USA 2002; 99: 4391-6.

92. Chadwick K, Wang L, Li L, Menendez P, Murdoch B, Rouleau A, Bhatia M. Cytokines and BMP-4 promote hematopoietic differentiation of human embryonic stem cells. Blood 2003; 102: 906-15.

93. Poon E, Clermont F, Firpo MT, Akhurst RJ. TGF $\beta$ inhibition of yolk-sac-like differentiation of human embryonic stem-cellderived embryoid bodies illustrates differences between early mouse and human development. J Cell Sci 2006; 119: 759-68.

94. Gouon-Evans V, Boussemart L, Gadue P, Nierhoff D, Koehler CI, Kubo A, Shafritz DA, Keller G. BMP-4 is required for hepatic specification of mouse embryonic stem cell-derived definitive endoderm. Nat Biotechnol 2006; 24: 1402-11.

95. Schmidt C, Bladt F, Goedecke S, Brinkmann V, Zschiesche W, Sharpe M, Gherardi E, Birchmeier C. Scatter factor/hepatocyte growth factor is essential for liver development. Nature 1995; 373: 699-702. 
96. Watanabe K, Kamiya D, Nishiyama A, Katayama T, Nozaki S, Kawasaki H, Watanabe Y, Mizuseki K, Sasai Y. Directed differentiation of telencephalic precursors from embryonic stem cells. Nat Neurosci 2005; 8: 288-96.

97. Ying QL, Stavridis M, Griffiths D, Li M, Smith A. Conversion of embryonic stem cells into neuroectodermal precursors in adherent monoculture. Nat Biotechnol 2003; 21: 183-6.

98. Yamamoto Y, Oelgeschläger M. Regulation of bone morphogenetic proteins in early embryonic development. Naturwissenschaften 2004; 91: 519-34.

99. Chambers SM, Fasano CA, Papapetrou EP, Tomishima M, Sadelain M, Studer L. Highly efficient neural conversion of human ES and iPS cells by dual inhibition of SMAD signaling. Nat Biotechnol 2009; 27: 275-80.

100. Mizuseki K, Sakamoto T, Watanabe K, Muguruma K, Ikeya M, Nishiyama A, Arakawa A, Suemori H, Nakatsuji N, Kawasaki H, Murakami F, Sasai Y. Generation of neural crest-derived peripheral neurons and floor plate cells from mouse and primate embryonic stem cells. Proc Natl Acad Sci USA 2003; 100: 5828-33.

101. Dreesen O, Brivanlou AH. Signaling pathways in cancer and embryonic stem cells. Stem Cell Rev 2007; 3: 7-17

102. Harley CB, Rao MS. Human embryonic vs. adult stem cells for transplantation therapies. In: Chiu AY, Rao MS, editors. Human embryonic stem cells. Totowa, NJ: Humana Press Inc., 2003: 239-64.

103. Derynck R, Piek E, Schneider RA, Choy L, Alliston T. TGF- $\beta$ family signaling in mesenchymal differentiation. In: Derynck R, Miyazono K, editors. The TGF-beta family. New York: Cold Spring Harbor Press, 2009: 613-65.

104. Chargé SB, Rudnicki MA. Cellular and molecular regulation of muscle regeneration. Physiol Rev 2004; 84: 209-38.

105. Roelen BA, Dijke P. Controlling mesenchymal stem cell differentiation by TGFBeta family members. Orthop Sci 2003; 8: $740-8$.

106. Liu D, Black BL, Derynck R. TGF-beta inhibits muscle differentiation through functional repression of myogenic transcription factors by Smad3. Genes Dev 2001; 15: 2950-66.

107. Walsh FS, Celeste AJ. Myostatin: a modulator of skeletalmuscle stem cells. Biochem Soc Trans 2005; 33: 1513-7.

108. Langley B, Thomas M, Bishop A, Sharma M, Gilmour S, Kambadur R. Myostatin inhibits myoblast differentiation by down-regulating MyoD expression. J Biol Chem 2002; 277: 49831-40.

109. Chen D, Zhao M, Mundy GR. Bone morphogenetic proteins. Growth Factors 2004; 22: 233-41.

110. Clever JL, Sakai Y, Wang RA, Schneider DB. Inefficient skeletal muscle repair in inhibitor of differentiation knockout mice suggests a crucial role for BMP signaling during adult muscle regeneration. Am J Physiol Cell Physiol 2010; 298: C1087-99.

111. Ruschke K, Hiepen C, Becker J, Knaus P. BMPs are mediators in tissue crosstalk of the regenerating musculoskeletal system. Cell Tissue Res 2012; 347: 521-44.

112. van der Kraan PM, Blaney Davidson EN, Blom A, van den Berg WB. TGF-beta signaling in chondrocyte terminal differentiation and osteoarthritis: modulation and integration of signaling pathways through receptor-Smads. Osteoarthritis Cartilage 2009; 17: 1539-45.

113. Ballock RT, Heydemann A, Wakefield LM, Flanders KC, Roberts AB, Sporn MB. TGF-beta 1 prevents hypertrophy of epiphyseal chondrocytes: regulation of gene expression for cartilage matrix proteins and metalloproteases. Dev Biol 1993; 158: 414-29.

114. Mueller MB, Tuan RS. Functional characterization of hypertrophy in chondrogenesis of human mesenchymal stem cells. Arthritis Rheum 2008; 58: 1377-88.

115. Tuli R, Tuli S, Nandi S, Huang X, Manner PA, Hozack WJ, Danielson KG, Hall DJ, Tuan RS. Transforming growth factorbeta-mediated chondrogenesis of human mesenchymal progenitor cells involves $\mathrm{N}$-cadherin and mitogen-activated protein kinase and Wnt signaling cross-talk. J Biol Chem 2003; 278: 41227-36.

116. Ferguson CM, Schwarz EM, Reynolds PR, Puzas JE, Rosier RN, O'Keefe RJ. Smad2 and 3 mediate transforming growth factorbeta1-induced inhibition of chondrocyte maturation. Endocrinology 2000; 141: 4728-35.

117. Docheva D, Haasters F, Schieker M. Mesenchymal stem cells and their cell surface receptors. Curr Rheumatol Rev 2008; 4: $155-60$.

118. Barry F, Boynton RE, Liu B, Murphy JM. Chondrogenic differentiation of mesenchymal stem cells from bone marrow: differentiation-dependent gene expression of matrix components. Exp Cell Res 2001; 268: 189-200.

119. Hwang NS, Zhang C, Hwang YS, Varghese S. Mesenchymal stem cell differentiation and roles in regenerative medicine. Wiley Interdiscip Rev Syst Biol Med 2009; 1: 97-106.

120. Sekiya I, Larson BL, Vuoristo JT, Reger RL, Prockop DJ. Comparison of effect of BMP-2, -4 , and -6 on in vitro cartilage formation of human adult stem cells from bone marrow stroma. Cell Tissue Res 2005; 320: 269-76.

121. Hanada K, Solchaga LA, Caplan AI, Hering TM, Goldberg VM, Yoo JU, Johnstone B. BMP-2 induction and TGF-beta 1 modulation of rat periosteal cell chondrogenesis. J Cell Biochem 2001; 81: 284-94.

122. Miljkovic ND, Cooper GM, Marra KG. Chondrogenesis, bone morphogenetic protein-4 and mesenchymal stem cells. Osteoarthritis Cartilage 2008; 16: 1121-30.

123. Bai X, Li G, Zhao C, Duan H, Qu F. BMP7 induces the differentiation of bone marrow-derived mesenchymal cells into chondrocytes. Med Biol Eng Comput 2011; 49: 687-92

124. Pittenger MF, Mackay AM, Beck SC, Jaiswal RK, Douglas R, Mosca JD, Moorman MA, Simonetti DW, Craig S, Marshak DR. Multilineage potential of adult human mesenchymal stem cells. Science 1999; 284: 143-7.

125. Noda M, Camilliere JJ. In vivo stimulation of bone formation by transforming growth factor-beta. Endocrinology 1989; 124 : 2991-4.

126. Joyce ME, Roberts AB, Sporn MB, Bolander ME. Transforming growth factor-beta and the initiation of chondrogenesis and osteogenesis in the rat femur. J Cell Biol 1990; 110: 2195-207.

127. Erlebacher A, Derynck R. Increased expression of TGF-beta 2 in osteoblasts results in an osteoporosis-like phenotype. J Cell Biol 1996; 132: 195-210.

128. Alliston T, Choy L, Ducy P, Karsenty G, Derynck R. TGF-betainduced repression of CBFA1 by Smad3 decreases CBFA1 and osteocalcin expression and inhibits osteoblast differentiation. EMBO J 2001; 20: 2254-72.

129. Zhou S. TGF-beta regulates beta-catenin signaling and osteoblast differentiation in human mesenchymal stem cells. J Cell Biochem 2011; 112: 1651-60.

130. Huang Z, Ren PG, Ma T, Smith RL, Goodman SB. Modulating osteogenesis of mesenchymal stem cells by modifying growth factor availability. Cytokine 2010; 51: 305-10. 
131. Wozney JM. Overview of bone morphogenetic proteins. Spine 2002; 27: S2-8.

132. Vukicevic S, Grgurevic L. BMP-6 and mesenchymal stem cell differentiation. Cytokine Growth Factor Rev 2009; 20: $441-8$.

133. Chen G, Deng C, Li YP. TGF- $\beta$ and BMP signaling in osteoblast differentiation and bone formation. Int J Biol Sci 2012; 8: 272-88.

134. Shen B, Bhargav D, Wei A, Williams LA, Tao H, Ma DD, Diwan AD. BMP-13 emerges as a potential inhibitor of bone formation Int J Biol Sci 2009; 5: 192-200.

135. Maeda S, Hayashi M, Komiya S, Imamura T, Miyazono K. Endogenous TGF-beta signaling suppresses maturation of osteoblastic mesenchymal cells. EMBO J 2004; 23: 552-63.

136. Singhatanadgit W, Salih V, Olsen I. Up-regulation of bone morphogenetic protein receptor IB by growth factors enhances BMP-2-induced human bone cell functions. J Cell Physiol 2006; 209: 912-22.

137. Yoshikawa H, Yoshioka K, Nakase T, Itoh K. Stimulation of ectopic bone formation in response to BMP-2 by Rho kinase inhibitor: a pilot study. Clin Orthop Relat Res 2009; 467: 3087-95.

138. Otto TC, Lane MD. Adipose development: From stem cell to adipocyte. Crit Rev Biochem Mol Biol 2005; 40: 229-42.

139. Lowe CE, O'Rahilly S, Rochford JJ. Adipogenesis at a glance. J Cell Sci 2011; 124: 2681-6.

140. Margoni A, Fotis L, Papavassiliou AG. The transforming growth factor-beta/bone morphogenetic protein signalling pathway in adipogenesis. Int J Biochem Cell Biol 2012; 44: 475-9.

141. Zamani N, Brown CW. Emerging roles for the transforming growth factor- $\{$ beta $\}$ superfamily in regulating adiposity and energy expenditure. Endocr Rev 2011; 32: 387-403.

142. Choy L, Skillington J, Derynck R. Roles of autocrine TGF-beta receptor and Smad signaling in adipocyte differentiation. J Cell Biol 2000; 49: 667-82.

143. Tsurutani Y, Fujimoto M, Takemoto M, Irisuna H, Koshizaka M, Onishi S, Ishikawa T, Mezawa M, He P, Honjo S, Maezawa Y, Saito Y, Yokote K. The roles of transforming growth factorbeta and Smad3 signaling in adipocyte differentiation and obesity. Biochem Biophys Res Commun 2011; 407: 68-73.

144. Zhang H, Schulz TJ, Espinoza DO, Huang TL, Emanuelli B, Kristiansen K, Tseng YH. Cross talk between insulin and bone morphogenetic protein signaling systems in brown adipogenesis. Mol Cell Biol 2010; 30: 4224-33.

145. Sottile V, Seuwen K. Bone morphogenetic protein-2 stimulates adipogenic differentiation of mesenchymal precursor cells in synergy with BRL 49653 (rosiglitazone). FEBS Lett 2000; 475: 201-4.

146. Hata K, Nishimura R, Ikeda F, Yamashita K, Matsubara T, Nokubi T, Yoneda T. Differential roles of Smad1 and p38 kinase in regulation of peroxisome proliferator-activating receptor gamma during bone morphogenetic protein 2-induced adipogenesis. Mol Biol Cell 2003; 14: 545-55.

147. Jin W, Takagi T, Kanesashi SN, Kurahashi T, Nomura T, Harada J, Ishii S. Schnurri-2 controls BMP-dependent adipogenesis via interaction with Smad proteins. Dev Cell 2006; 10: 461-71.
148. Taha MF, Valojerdi MR, Mowla SJ. Effect of bone morphogenetic protein-4 (BMP-4) on adipocyte differentiation from mouse embryonic stem cells. Anat Histol Embryol 2006; 35: 271-8.

149. Stewart A, Guan H, Yang K. BMP-3 promotes mesenchymal stem cell proliferation through the TGF-beta/activin signaling pathway. J Cell Physiol 2011; 223: 658-66.

150. Tseng YH, Kokkotou E, Schulz TJ, Huang TL, Winnay JN, Taniguchi CM, Tran TT, Suzuki R, Espinoza DO, Yamamoto Y, Ahrens MJ, DudleyAT, Norris AW, Kulkarni RN, Kahn CR. New role of bone morphogenetic protein 7 in brown adipogenesis and energy expenditure. Nature 2008; 454: 1000-4.

151. Rebbapragada A, Benchabane H, Wrana JL, Celeste AJ, Attisano L. Myostatin signals through a transforming growth factor beta-like signaling pathway to block adipogenesis. Mol Cell Biol 2003; 23: 7230-42.

152. Feldman BJ, Streeper RS, Farese Jr RV, Yamamoto KR. Myostatin modulates adipogenesis to generate adipocytes with favorable metabolic effects. Proc Natl Acad Sci USA 2006; 103: $15675-80$.

153. Guo W, Flanagan J, Jasuja R, Kirkland J, Jiang L, Bhasin S. The effects of myostatin on adipogenic differentiation of human bone marrow-derived mesenchymal stem cells are mediated through cross-communication between Smad3 and Wnt/beta-catenin signaling pathways. J Biol Chem 2008; 283: 9136-45.

154. Hino J, Miyazawa T, Miyazato M, Kangawa K. Bone morphogenetic protein-3b (BMP-3b) is expressed in adipocytes and inhibits adipogenesis as a unique complex. Int $\mathrm{J}$ Obes (Lond) 2012; 36: 725-34.

155. Kalluri R, Weinberg RA. The basics of epithelial-mesenchymal transition. J Clin Invest 2009; 119: 1420-8.

156. Battula VL, Evans KW, Hollier BG, Shi Y, Marini FC, Ayyanan A, Wang RY, Brisken C, Guerra R, Andreeff M, Mani SA. Epithelial-mesenchymal transition-derived cells exhibit multilineage differentiation potential similar to mesenchymal stem cells. Stem Cells 2010; 28: 1435-45.

157. Goumans MJ, van Zonneveld AJ, ten Dijke P. Transforming growth factor beta-induced endothelial-to-mesenchymal transition: a switch to cardiac fibrosis? Trends Cardiovasc Med 2008; 18: 293-8.

158. Kuhn NZ, Tuan RS. Regulation of stemness and stem cell niche of mesenchymal stem cells: implications in tumorigenesis and metastasis. J Cell Physiol 2010; 222: 268-77.

159. Saj A, Lai EC. Control of microRNA biogenesis and transcription by cell signaling pathways. Curr Opin Genet Dev 2011; 21: 504-10.

160. Guo L, Zhao RC, Wu Y. The role of microRNAs in self-renewal and differentiation of mesenchymal stem cells. Exp Hematol 2011; 39: 608-16.

161. Tiscornia G, Izpisúa Belmonte JC. MicroRNAs in embryonic stem cell function and fate. Genes Dev 2010; 24: 2732-41.

162. Graham H, Peng C. Activin receptor-like kinases: structure, function and clinical implications. Endocr Metab Immune Disord Drug Targets 2006; 6: 45-58.

Received April 5, 2012; accepted June 15, 2012 


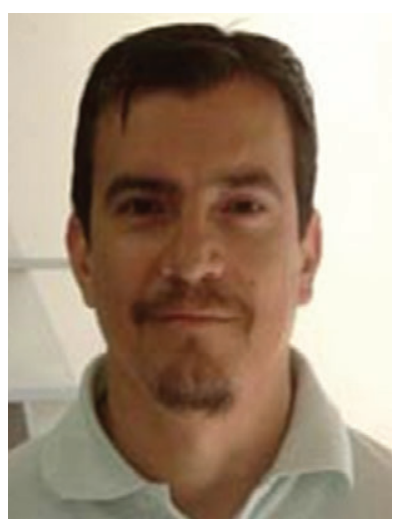

Dr. Juan F. Santibanez received his $\mathrm{PhD}$ from the Instituto de Investigaciones Biomédicas "Alberto Sols" (IIBM), Spain in 1999, worked as a postdoctoral fellow at the "Centro de Investigaciones Biologicas, CIB", Spain from 2003 to 2005. Dr. Santibanez was Research Associated (19911995), Instructor (-1999) and Assistant Professor (-2008) at the Laboratory for Cellular Research, INTA, Universidad de Chile. He is currently a Professor of Research at the Institute for Medical Research, IMI, Belgrade, Serbia. His major research area is the role of TGF- $\beta$ in tumor progression and in endothelial cells, and recently has become interested in mesenchymal stem cells biology.

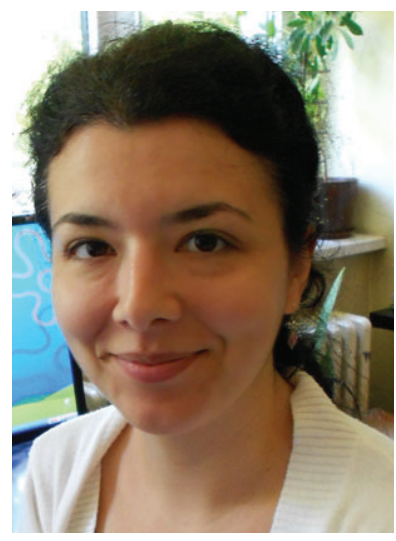

Jelena Kocic graduated from the University of Belgrade, Serbia in 2007 with Bachelor's degree in Biology and is currently pursuing her Doctorate in Biology. She is a Research Associate at the Institute for Medical Research, University of Belgrade, Serbia. Her scientific interests include research of signaling pathways activated by TGF- $\beta$ during epithelial-mesenchymal transition, as well as isolation and characterization of adult stem cells and research of IL-17 signaling activated during stem cell differentiation. 